\title{
The central nervous system in motor neurone disease
}

\author{
BETTY BROWNELL ${ }^{1}$, D. R. OPPENHEIMER, AND J. TREVOR HUGHES \\ From the Department of Neuropathology, Radcliffe Infirmary, Oxford
}

SUMMARY Forty-five necropsied cases with primary degeneration of lower motor neurones are described and discussed. Of these, 36 are considered to be 'typical' cases of motor neurone disease, $\frac{\bar{T}}{\varnothing}$ eight of which showed no upper motor neurone lesions. The relation of the nine 'atypical' cases to the remainder is discussed. It is concluded that motor neurone disease constitutes an ill-defined banden in a broad spectrum of multiple system atrophies. The authors have found no evidence suggesting $2 \overrightarrow{0}$ causal relation between motor neurone disease and either vascular or malignant diseases. They point out suggestive analogies with various subacute encephalomyelopathies in man and other animals $\underset{\odot}{\omega}$

This paper presents the results of a re-examination of pathological material from all the cases examined at necropsy in this department in 12 years (1957 to 1968), on which we had reached a firm or tentative pathological diagnosis of motor neurone disease. The survey was undertaken because we felt that we were using this diagnosis, for lack of a suitable alternative, to cover conditions which had very little in common. We felt that we might be dealing with more than one kind of pathological process, and that some of these processes might become more apparent from a reappraisal of a fairly large series, paying special attention to difficult or atypical cases.

\section{SELECTION OF CASES}

The primary basis of selection was loss of cells in spinal and/or cranial motor nuclei. We excluded cases in which this loss was attributable to infections -for instance, tabes dorsalis-tissue anoxia, or mechanical compression of the spinal cord or nerves; but did not exclude cases with concomitant vascular disease, when this alone was insufficient to account for the lesions. We excluded cases of peroneal muscular atrophy (Charcot-Marie-Tooth disease) and of familial spinal muscular atrophy of infancy (Werdnig-Hoffmann disease). Cases with onset in the second or third decades would not have been excluded, had there been any. In every case we had reasonable clinical information and post-mortem

'Present address: The Burden Neuropathological Laboratory, Frenchay Hospital, Bristol. material including the brain and spinal cord. In but six we had specimens of muscle, usually reppeies sentative of bulbar, cervical, and lumbo-sacral inneres vation. In all we examined 45 cases. The main clinisad and pathological features of these are set out Table 1.

METHODS

CLINICAL As far as possible, we abstracted the following information from the clinical notes: relevant family history; sex; age of patient at onset and at death; duration of disease in months; site of first symptoms (bulbars upper or lower limbs); involvement of these sites at las examination; signs of lower motor neur one involvemenfy (wasting, fasciculation); signs of upper motor neuron 8 involvement (extensor plantar responses, pathological tendon reflexes); signs of concomitant disease, neurog logical or other, including evidence of dementia; and the final clinical diagnosis.

PATHOLOGICAL In the brain, we looked for gross changes including cerebral atrophy, and examined representative areas of cortex (in particular the motor cortex), thalamus and basal ganglia for signs of cell loss or abnormal gliosiş Gliosis was assessed in frozen sections impregnated with Cajal's gold sublimate, and in celloidin or paraffin seco tions stained with either phosphotungstic acid or Holzer? method. The cerebellum was examined in routine cell ang myelin stains, and the brain-stem similarly, with special attention to the 5th, 7th, 10th, and 12th motor nucles

The spinal cord was sectioned at five or more levels, always including the cervical and lumbosacral enlarges ments, and a thoracic segment. The following chang 95 were looked for: (1) loss of large motor cells at each leve and pathological changes in remaining cells; (2) loss $\mathscr{Q} \mathrm{E}$ 
TABLE 1

${ }^{1} \mathrm{~L}$ : lower limb

U: upper limb

B: bulbar muscles

${ }^{2} \mathrm{C}$ : cervical cord

P: medullary pyramids

M: midbrain

$\mathrm{H}$ : cerebral hemispheres

${ }^{3} \mathrm{C}$ : cortex

Gp: globus pallidus

St: striatum

Sn: Subst. nigra

Sub: Subthalamic n.

$\mathrm{T}$ : Thalamus

$-=$ no lesion seen

$\mathrm{O}=$ material not available Special features

Abnormal pyruvate metabolisn? Hypertension. Right hemiplegia infarct in left internal capsule 0

Hypertension. Old left temporad lobe haemorrhage

\section{$\begin{array}{lllll}5 & \text { M } & 58 & 25 & \text { B }\end{array}$ \\ $\begin{array}{lllll}6 & \mathrm{M} & 62 & 28 & \mathrm{~B}\end{array}$ \\ $\begin{array}{lllll}7 & \text { M } & 66 & 12 & \text { L }\end{array}$}

\begin{tabular}{l|l}
+ & -+1 \\
\hline$+-t$ & +
\end{tabular}

\begin{tabular}{lllll}
\hline 8 & F & 76 & 18 & U
\end{tabular}

\begin{tabular}{ccccc}
\hline 9 & F & 50 & 11 & U \\
\hline
\end{tabular}

\begin{tabular}{lllll}
\hline 10 & M & 55 & 54 & L
\end{tabular}

$\begin{array}{lllll}11 & \mathrm{M} & 58 & 30 & \mathrm{~L}\end{array}$

$\begin{array}{lllll}112 & \text { M } & 60 & 26 & \text { L }\end{array}$

\begin{tabular}{lllll}
\hline 13 & F & 60 & 30 & B
\end{tabular}

\begin{tabular}{lllll}
\hline 14 & F & 60 & 19 & B
\end{tabular}

$\begin{array}{lllll}15 & \text { F } & 68 & 24 & \text { L }\end{array}$

\begin{tabular}{lllll}
\hline 16 & $\mathrm{M}$ & 70 & 42 & $\mathrm{~B}$
\end{tabular}

$\begin{array}{lllll}17 & \mathrm{~F} & 45 & 22 & \mathrm{U}\end{array}$

\begin{tabular}{lllll}
\hline 18 & M & 45 & 13 & B \\
\hline
\end{tabular}

\begin{tabular}{lllll}
\hline 19 & M & 46 & 16 & B
\end{tabular}

\begin{tabular}{lllll}
\hline 20 & M & 46 & 36 & L
\end{tabular}

$\begin{array}{lllll}21 & \text { F } & 47 & 24 & \text { L }\end{array}$

$\begin{array}{lllll}22 & \text { M } & 47 & 24 & \text { B }\end{array}$

$\begin{array}{llllll}23 & \text { F } & 55 & 48 & \text { LU }\end{array}$

\begin{tabular}{lllll}
24 & $F$ & 55 & 24 & $U$ \\
\hline 25 & $F$ & 55 & 15 & $U$
\end{tabular}

$\begin{array}{lllll}25 & \text { F } & 55 & 15 & \text { U }\end{array}$

\begin{tabular}{lllll}
\hline 26 & M & 56 & 22 & L
\end{tabular}

\begin{tabular}{lllll}
\hline 27 & F & 57 & 25 & L
\end{tabular}

\begin{tabular}{lllll}
\hline 28 & M & 59 & 16 & B \\
\hline
\end{tabular}

$\begin{array}{llllll}29 & \text { M } & 60 & 11 & \text { LUB }\end{array}$

\begin{tabular}{lllll}
\hline 30 & F & 63 & 16 & B \\
\hline
\end{tabular}

$\begin{array}{lllll}31 & \mathrm{~F} & 64 & 42 & \mathrm{~L}\end{array}$

$\begin{array}{lllll}32 & \text { F } & 69 & 24 & \text { LUB }\end{array}$

$33 \quad \mathrm{M}<80 \quad ? \quad$ ?

\begin{tabular}{lllll}
\hline 34 & $\mathrm{~F}$ & 58 & 48 & $\mathrm{~L}$
\end{tabular}

\begin{tabular}{lllll}
\hline 35 & M & 67 & 8 & LU
\end{tabular}

\begin{tabular}{rlrrr}
\hline 36 & F & 68 & 30 & LU \\
\hline 37 & M & 44 & 132 & L
\end{tabular}

\begin{tabular}{llllll}
\hline 37 & M & 44 & 132 & L \\
\hline 38 & F & 49 & 120 & L
\end{tabular}

$\begin{array}{llllll}39 & F & 52 & 22 & \text { L }\end{array}$

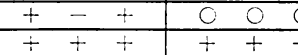

$++t$
$++t$

\begin{tabular}{|c|c|c|}
\hline+ & + & + \\
\hline+ & $=$ & - \\
\hline 7 & + & - \\
\hline+ & + & + \\
\hline+ & + & + \\
\hline+ & - & + \\
\hline+ & $t$ & - \\
\hline
\end{tabular}

$+++1++$

\begin{tabular}{lllll|lll}
- & - & - & - & - & - & + & CT \\
- & - & - & - & + & + & + & CT St \\
- & - & - & - & + & + & + & Sub
\end{tabular}

Thyrotoxic. Angioma of left in ternal capsule

Focal and laminar cortical celt loss

\begin{tabular}{|c|c|c|c|c|c|c|c|c|c|c|c|c|c|c|}
\hline 0 & $\overline{0}$ & $\overline{0}$ & + & t & + & t & & $=$ & $=$ & $=$ & $=$ & t & & \\
\hline+ & t & + & $\begin{array}{c}t \\
t\end{array}$ & + & t & + & $\mathbf{C}$ & - & - & + & - & + & & \\
\hline+ & t & + & + & + & + & + & $\overline{\mathbf{M}}$ & - & - & + & - & $+\mathbf{T ~ S t}$ & Hypertension. Suicide & \\
\hline $\mathrm{O}$ & + & + & + & + & + & + & $\mathbf{H}$ & - & - & + & $t$ & + & & \\
\hline t & t & t & $t$ & + & + & + & $\mathbf{H}$ & - & - & - & - & + & & \\
\hline+ & + & + & + & + & + & + & $\mathbf{M}$ & $=$ & - & $=$ & - & $-\quad$ CT Gp & Old radical mastectomy & \\
\hline+ & $\mathrm{O}$ & $\mathrm{O}$ & & + & - & t & $\mathbf{C}$ & - & - & t & $t$ & + & Endocrine disorders. & \\
\hline
\end{tabular}
ostosis frontalis

\begin{tabular}{lllll}
\hline 40 & F & 54 & 16 & U \\
\hline
\end{tabular}

+-+
+++

Status spongiosus of cerebrat cortex

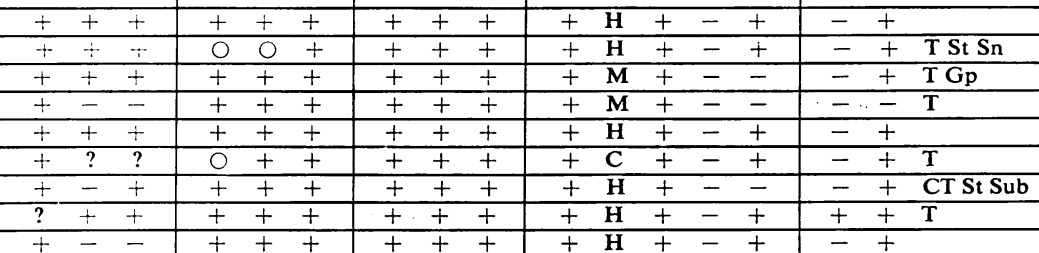

Old cerebral trauma

$$
\begin{array}{lllll}
41 & \text { M } & 66 & 30 & \text { U }
\end{array}
$$

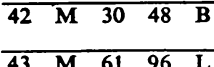

$+++$

$++t$

\begin{tabular}{r|r}
++ & + \\
+ & +
\end{tabular}

\begin{tabular}{r|r}
-+ & + \\
-+ & + \\
\hline
\end{tabular}

\begin{tabular}{|c|c|c|}
\hline$+\mathbf{H}$ & + & $=$ \\
\hline$+\mathbf{H}$ & + & - \\
\hline
\end{tabular}

\begin{tabular}{|c|c|}
\hline & $+\mathrm{CT}$ \\
\hline- & + \\
\hline 7 & + \\
\hline- & $+\mathrm{CT} \mathrm{St}$ \\
\hline \pm & $+\quad \mathrm{CT}$ \\
\hline \pm & + \\
\hline- & + T St \\
\hline- & - \\
\hline+ & $+\mathrm{T}$ \\
\hline 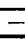 & $+\quad$ T Gp \\
\hline
\end{tabular}

Widespread vascular disease $\overline{0}$ Status spongiosus of cortex

\section{Carcinoma of kidney}

Dementia. Old head injury, subdural haematoma

Hypertension. Terminal cerebra haemorrhage

Parkinsonism. Widespread vasocular disease

Hypertension

Hypertension. von Willebrand's disease

Hypertension. Mastectomy for carcinoma

Mild dementia

Status spongiosus of motor cortex

Sensory disturbances. Telans $O$ giectasia in pons

Myelomatosis. Pes cavus

Clarke's column and spino- $\omega$ cerebellar tract degeneration

Clarke's column and spino cerebellar tract degeneration 0 
cells in the dorsal and intermediolateral cell columns; (3) loss of myelin in posterior, lateral, and anterior columns, or around the margin of the cord; (4) degeneration of individual tracts, in particular the pyramidal and spinocerebellar tracts; (5) loss of fibres in nerve roots; (6) abnormal fibrosis of nerve roots and leptomeninges; (7) signs of vascular disease.

Degeneration in the pyramidal tracts was looked for in paraffin sections stained for myelin and in frozen sections stained by a Marchi method (Glees, 1943) ${ }^{1}$, up to the level of the internal capsule. When degeneration was present at lower but not higher levels, the upper limit was noted.

Muscles from upper and lower limbs, and samples of bulbar muscles (usually tongue) were examined for evidence of denervation atrophy.

\section{RESULTS}

Thirty-six out of the 45 cases in our series (four-fifths of the total) showed the following clinical and pathological features:

CLINICAL (1) Onset after the age of 44 ; (2) unremitting progressive history of muscular weakness; (3) death in less than five years; (4) absence of sensory impairment; (5) negative family history.

Pathological (1) Substantial loss of lower motor nerve cells; (2) no degeneration in the posterior columns or in the spinocerebellar tracts; (3) no loss of cells in any part of the cerebellar system.

We have chosen to regard these 36 cases as 'typical' cases of motor neurone disease. Within this group there are, of course, clinical and pathological variations, which will be discussed below; but these variations seem to us to be part of a continuum, and do not warrant any sharp division of the group into nosological 'entities'. These 'typical' cases will be described together. In the nine cases which fall outside the arbitrary limits given above, a more detailed description will be given.

\section{OBSERVATIONS ON 36 'TYPICAL' CASES}

\section{CLINICAL}

Eighteen cases were male, 18 female. The mean age

${ }^{1}$ The Marchi method, though admirable for tracing diffuse fibre degeneration in the cerebrum in fresh material (Smith, 1960), proved to be of little help in showing degeneration in well-defined tracts. Where it gave positive results, we were always able to see local pallor in the standard myelin preparations; and it gave negative results in many cases where myelin pallor was obvious. The reasons for this appeared to be (1) removal of Marchi products during life in cases with slow progression, and (2) disappearance of recently-formed Marchi products in long-stored material (Smith, 1956). On the other hand, some Marchi-positive material was nearly always present where pyramidal tract degeneration was severe, even after 10 years' storage in formalin. of onset was $57 \frac{1}{2}$, with a range from 44 to 79 years The mean for males was $56 \frac{1}{2}$, for females $58 \frac{1}{2}$ years $Z$ The duration of the disease ranged from two months to $4 \frac{1}{2}$ years, with a mean of 24.4 months. For males the mean was $22 \cdot 2$, for females 26.4 months. The earliest signs of weakness were in the legs in 25 cases in the upper limbs in 13, and in the bulbar musculas ture in 14 (in many cases, the initial symptoms were? referred more or less simultaneously to different regions). Onset in the limbs was often asymmetrica $\vec{R}$ at first, but later tended to become symmetrical. It was noted that the mean duration of the disease in? the cases with bulbar onset was 20 months-abou? $4 \frac{1}{2}$ months less than the mean for the whole group음 In no case was there any clinical record of others members of the family suffering from a similar disease; and in no case was there a record of polio myelitis in early life. A final clinical diagnosis of motor neurone disease (or progressive muscular: atrophy, or progressive bulbar palsy, or amyotrophic lateral sclerosis) was made in 32 cases. Other diags noses included myopathy, multiple sclerosis, atypica Parkinsonism, and intervertebral disc disease.

An initial diagnosis of myelopathy due to cervica spondylosis was often made, on the principle thotit treatment for this condition could do no harm, a a d might do good.

\section{PATHOLOGICAL}

CHANGES IN MOTOR NUCLEI These consisted in (a) loss of motor cells (Fig. 1), associated with loss §ో:0 axons in anterior spinal roots; (b) a variable degeed of gliosis; (c) a variety of morphological changes, including shrinkage and pyknosis, loss of staining properties ('ghost cells'), and neuronophagia (Figs. $2 \mathrm{a}, \mathrm{b})$. Central chromatolysis was never observed, but in one or two cases we saw vacuolation of the cytoplasm.

We made no attempt to assess the degree of cello $\overrightarrow{\overrightarrow{0}}$ loss, as in nearly all cases we had specimens of muscle, which provided a more reliable index of denervation. We recorded the presence or absence of manifest cell loss in the lumbar enlargement, cervical enlargement and hypoglossal nuclei. We also? examined levels of brain-stem showing the trigeminalo motor nuclei, facial nuclei, and nuclei ambigui. In all these, characteristic cell changes were frequentlyô observed (Fig. 2b), but we were unable to make reliable judgements on the presence or absence of 윽 cell loss. Cell loss was seen at all three levels-lumbar, $D$ cervical, and medullary-in 30 cases. In three, the lumbar and cervical segments were affected, but not $\bar{N}$ the bulbar; in three, the lumbar segment was spared,and the cervical and bulbar ones were affected. In $N$ several instances, the sparing was only relative, as the 


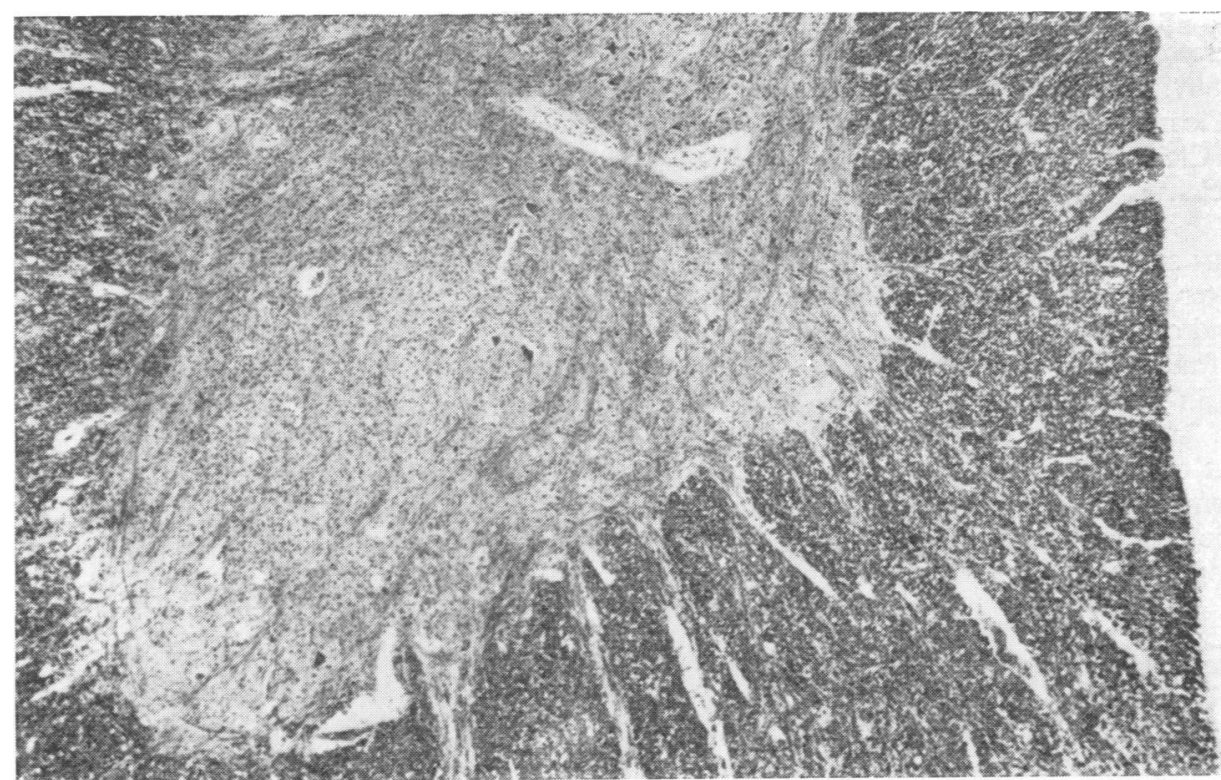

FIG. 1. Case 31. Lumbar enlargement, showing loss of motor neurones and glial proliferation. Luxol fast blue/cresyl violet, $\times 40$.

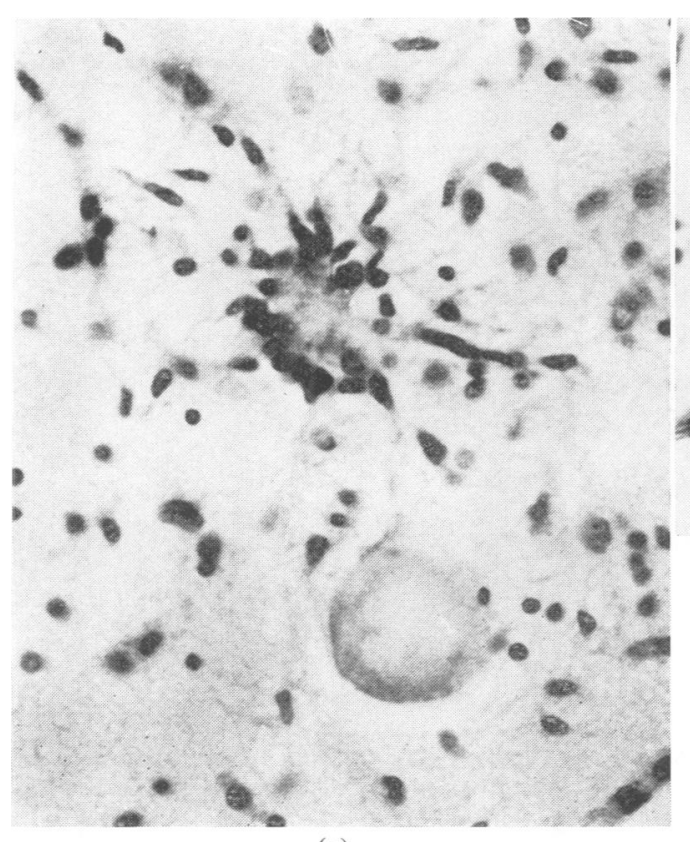

(a)

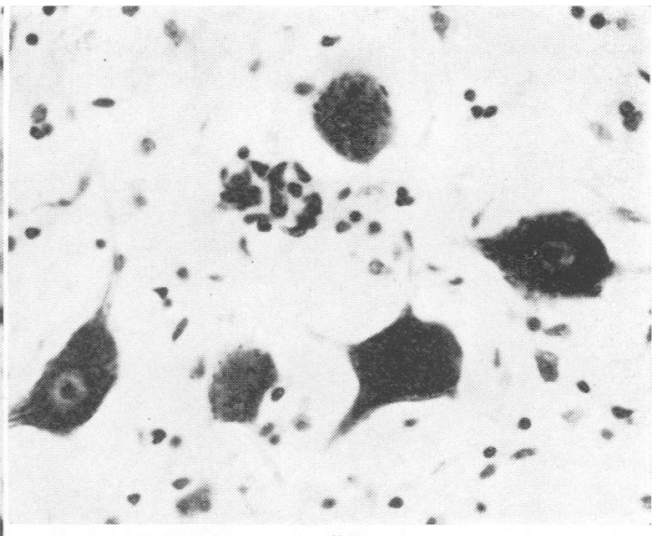

(b)

FIG. 2. (a) Case 2. Neuronophagia and 'ghost cell' in anterior horn. Nissl, $\times 345$. (b) Case 32 . Neuronophagia in facial nucleus. Nissl, $\times 300$. 
corresponding muscle was found to show at least a minor degree of denervation. Only in a few cases was there an obvious disparity in cell loss on the two sides. Cell loss was specifically looked for, and never found, in Clarke's columns and in the intermediolateral nuclei.

CHANGES IN SPINAL WHITE MATTER The pattern of white matter degeneration in the cord was variable (Fig. 3) and on this basis we were able to assign the cases to four groups, thus: (1) no degeneration detectable in myelin or Marchi preparations: eight cases (Fig. 3a); (2) degeneration in pyramidal tracts only: eight cases (Fig. 3b); (3) anterior and lateral white columns affected, the pyramidal tracts more so than the rest; posterior white columns intact: 17 cases (Fig. 3c); (4) as in (3) but with some degeneration in posterior columns: three cases (Fig. 3d).

This grouping was arbitrary in that there was $\mathrm{a} \subseteq$ continuous variation in the pattern of degeneration in the spinal white matter. The assignment of a case to a particular group was often difficult, as there were several cases with asymmetrical lesions-for example, with one side of the cord showing pyramidal degeneration, the other side not, or else with bilateral pyramidal degeneration but unilateral myelin pallor in the rest of the anterior and lateral columns. This continuous variation has to be borne in mind when considering the clinical features of the four groups, which are as follows:

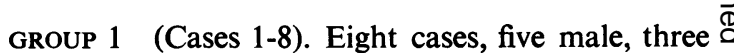
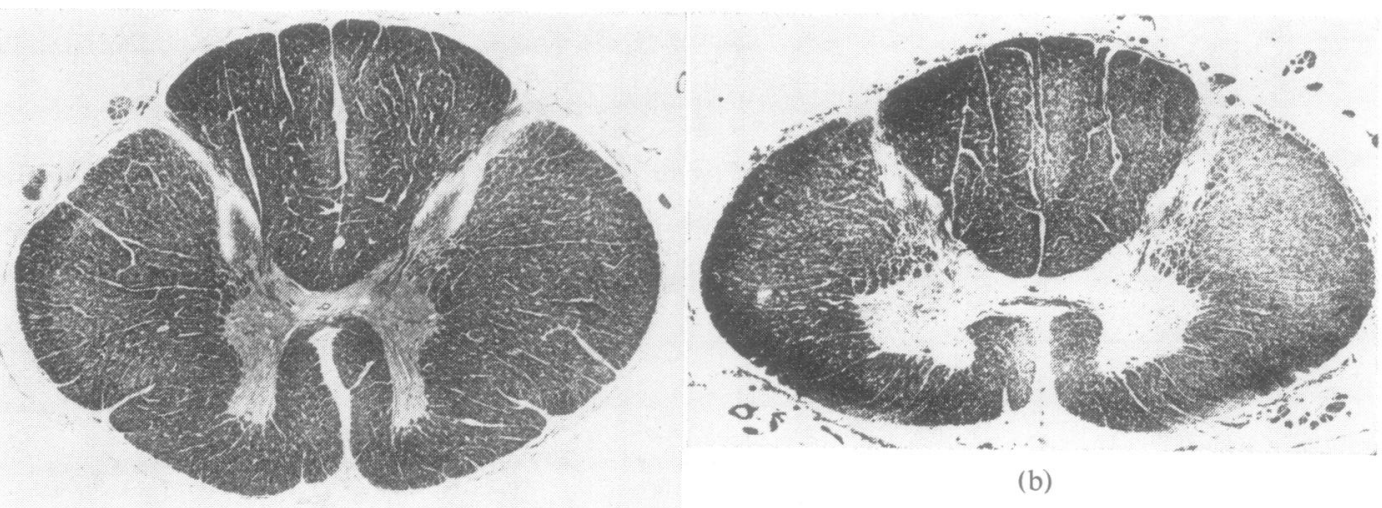

(b)

(a)

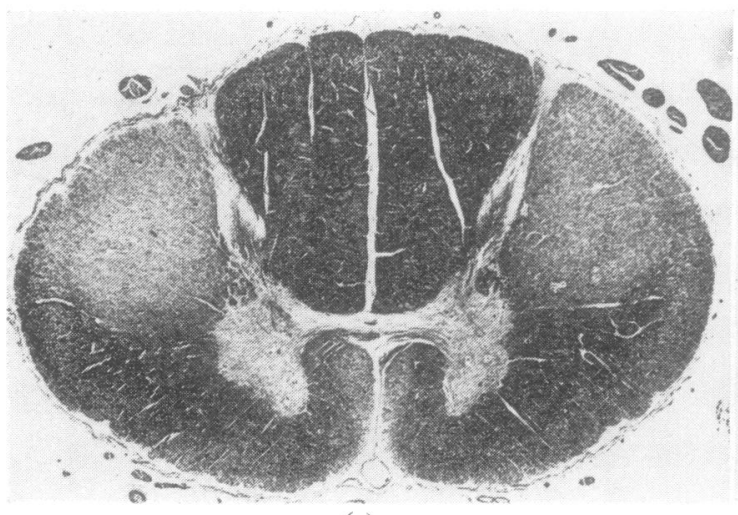

(c)

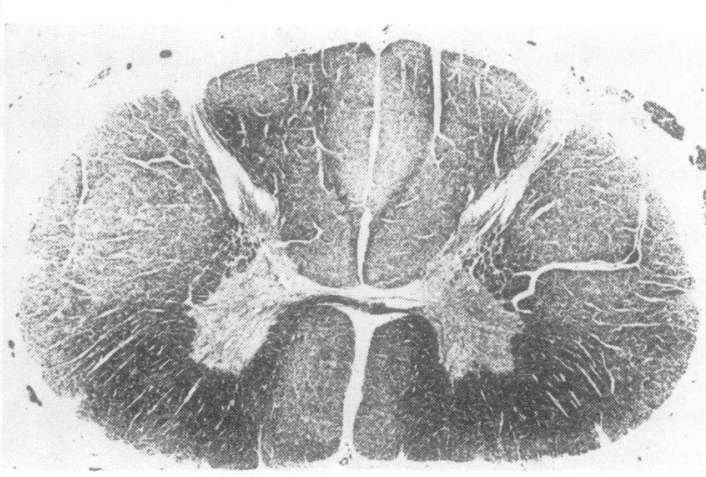

(d)

FIG. 3. Transverse sections of cervical cord stained for myelin and showing patterns of myelin pallor. (a) Case 6. Group 1. O Normal myelin. (b) Case 16. Group 2. Asymmetrical pallor in crossed and uncrossed pyramidal tracts. (c) Case 18. Group 3. N Severe pallor of crossed and uncrossed pyramidal tracts; some pallor of anterior and lateral columns. (d) Case 35 . Group 4 . N As (c) with the addition of posterior column degeneration. 
female, four with bulbar onset. Mean age of onset, $58 \frac{1}{2}$ years. Mean duration, 18 months.

GROUP 2 (Cases 9-16). Eight cases, four male, four female. Three with bulbar onset. Mean age of onset, 61 years. Mean duration, 29.5 months.

GROUP 3 (Cases 17-33). Seventeen cases, eight male, nine female. Seven with bulbar onset. Mean age of onset, 54 years. Mean duration, 23 months.

GROUP 4 (Cases 34-36). Three cases, one male, two female. None with bulbar onset. Mean age of onset, 64 years. Mean duration, 29 months.

PYRAMIDAL DEGENERATION IN GROUPS 2, 3, AND 4 This was assessed on the basis of myelin pallor in the spinal cord and brain-stem. Where the pallor was severe, comparison with sections impregnated for axis cylinders showed a definite fibre loss; thus the process may be regarded as a true degeneration rather than as a demyelination. We found, as others have done, that pyramidal degeneration tends to be more severe at lower than at higher levels, and may be undetectable in the brain-stem when it is clearly marked in the cord. In 12 cases, there were upper limits above which no degeneration could be seen (Table 1). In this respect, there was an apparent difference between groups 2 and 3. In group 2, out of eight cases there were only three in which degeneration reached the cerebral hemispheres; while in group 3,12 out of 17 showed degeneration in the internal capsule. Extension to the hemispheres was usually associated with a more intense degeneration at lower levels.

MYELIN PALLOR OF ANTERIOR AND LATERAL COLUMNS IN GROUPS 3 AND 4 In all cases, this took the form of a relative pallor of these columns, as compared with the posterior columns, in myelin preparations. In silver preparations, the loss of fibres was generally not severe enough to be obvious, except in the pyramidal tracts. Specific degeneration of spinocerebellar tracts was never observed.

MYELIN PALLOR OF POSTERIOR COLUMNS IN GROUP 4 A degree of pallor in the columns of Goll is a common finding in the cords of elderly people, but its cause is not always apparent. In cases 34,35 , and 36 it was more marked than usual. In case 35 , it could be traced to an ischaemic region in the lower cord and to loss of fibres in some of the sacral posterior roots. In cases 34 and 36, pallor of the posterior columns was seen only in the thoracic and cervical segments. All three patients were hypertensive, with widespread cardiovascular disease.

MYELIN PALLOR OF THE MARGINAL (SUBPIAL) ZONE This, too, is a fairly common finding in the cords of elderly subjects. It is usually easy to distinguish it from poor staining due to rough handling of the cord post-mortem. It is also distinguished from specific degeneration of the spinocerebellar tracts by the fact that it extends all round the anterior and posterior margins of the cord, and is not associated with loss of cells in Clarke's columns. About half the cases in our series showed this marginal pallor (Fig. 4). In many, but not all, it was associated with some fibrous thickening of the pia mater.

ASSOCIATED VASCULAR DISEASE In no case did we observe any abnormality of anterior or posterior spinal arteries or of spinal veins. In all cases but one (case 35 ) the small vessels within the cord were entirely normal, and in only two (cases 2 and 35) did we consider that lesions attributable to vascular in-

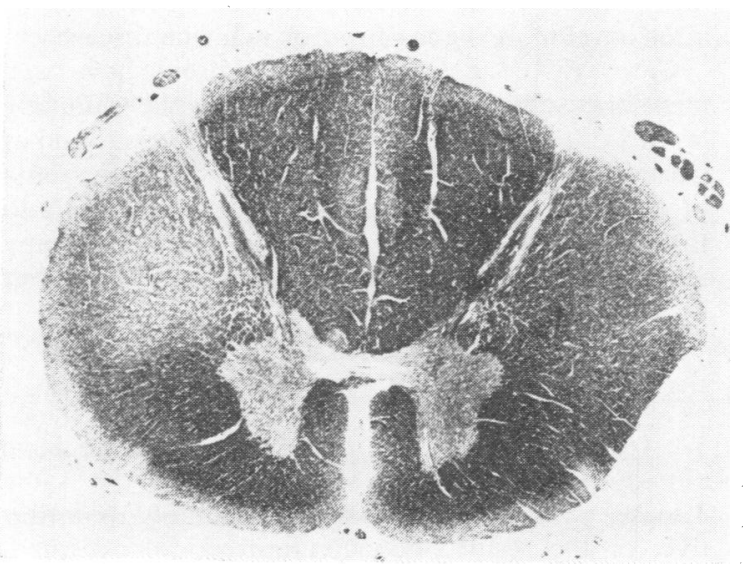

FIG. 4. Case 11. Transverse section of cervical cord stained for myelin and showing asymmetrical pallor of pyramidal tracts, with an additional marginal zone of myelin pallor. 
sufficiency were present in the cord. Case 2 had a small spongy lesion of the anterior white matter seen only at $\mathrm{T} 4$, which we considered to be a vascular softening, although we found no abnormality of any vessel. Case 35, which has been reported in detail elsewhere (Hughes and Brownell, 1966) had severe cardiovascular disease with atheroma and thrombosis of the lower aorta; the lower spinal segments showed, in addition to motor cell loss and pyramidal tract degeneration, multiple small foci of necrosis in the white matter, and hyaline thickening of small arteries and capillaries. In the presence of these vascular lesions, the diagnosis of motor neurone disease depended mainly on the findings in the brain (symmetricaldegeneration of the pyramidal tracts)and of the intramedullary parts of the facial nerves, and specific cell loss in the motor nuclei, with denervation of the tongue. We thought that this case was an example of vascular insufficiency superimposed upon the changes of motor neurone disease.

Vascular disease of the cerebrum was present in three cases in the series (cases 3, 7, and 34). In case 3 the changes of motor neurone disease were complicated by cerebral atheroma and a small infarct in one internal capsule, giving rise to unilateral pyramidal tract degeneration. Case 7 had an angioma in one internal capsule which had caused a small haemorrhage, and case 34 had a massive terminal intracerebral haemorrhage.

Hypertensive or arteriosclerotic cardiovascular disease was present in seven cases, including two of the three mentioned above (cases 3 and 34).

CHANGES IN THE BRAIN A mild generalized cerebral atrophy was found in 11 cases. Histologically there were cell changes, cell loss, and gliosis in motor nuclei. No other changes were seen in the brainstem, apart from pyramidal tract degeneration. Some loss of Purkinje cells in the cerebellar cortex was often seen, but not in excess of what is frequently observed in this age group. Other parts of the cerebellum appeared intact.

Except in one case, we did not attempt to plot the distribution of Marchi degeneration through the hemispheres, but restricted our attention to the corticospinal tracts. When degeneration was present, we found it, as Bertrand and van Bogaert (1925) and others have done, in a restricted zone in the posterior part of the posterior limb of the internal capsule, and not, as is sometimes stated, in the anterior two-thirds (Figs. 5 and 6). In several cases, scattered degenerating fibres were seen in the thalamus and in the globu; pallidus. In case 18 , we traced the degeneration to higher levels, and found a well-defined band of degeneration in the corpus callosum (presumably affecting fibres connecting the left and right Rolandic areas). Above this level, both the pyramidal tract and the callosal band became more diffuse, and were traceable to a large area of cortex, including the pre-central and post-central convolutions (Fig. 6). Our findings in this case were very similar to those of Probst $(1898,1903)$.

We were unable to detect cell loss in any of the basal nuclei; but in 20 cases we noted a reactive astrocytosis in one or more of these structures (Fig. 7) (see Table 1), in excess of what could be dismissed as a commonplace senile change. The thalamus was affected in 19 cases, most commonly in the ventral nuclear complex, but also, less frequently, in other areas. The striatum was affected in seven cases, the globus pallidus in three, the subthalamic nucleus in two, and the substantia nigra in one. (These figures are probably too low, as in several cases we were unable to obtain satisfactory glial stains.) In the absence of demonstrable cell loss we were inclined to attribute this astrocytic gliosis to degeneration of nerve fibres en passage.

Paucity, or absence, of giant pyramidal cells in the pre-zentral gyrus was noted in all but six cases. It is worth noting that of the eight cases in group 1 -that is, those with no evidence of pyramidal tract degen $\omega$ eration-six showed loss of giant cells. Other cortica $\omega_{W}$ areas were not examined systematically. We did nof $\infty$ observe laminar or focal loss of cells other than giand cells; but in 10 cases we noted an abnormal degree $\mathbb{}$ astrocytic activity in some part of the cortex (Fig. 8) and in two cases this was combined with a mito degree of status spongiosus in layers 2 and 3.

CAUSES OF DEATH AND MISCELLANEOUS FINDINGS With few exceptions, the cause of death was respiratory failure, often complicated by a terminal aspiration pneumonia. Pulmonary embolism caused death in three cases, and cerebral haemorrhage in one. One committed suicide by electrocution. One (case 3) died of pneumonia and heart failure only two months after developing signs of motor neurone disease.

Cases with concomitant vascular disease have been mentioned above. Two cases showed old traumatic lesions of the brain. Only one (case 28) was found at necropsy to have malignant disease (adenocarcinoma of the kidney; there were no symptoms referable to this). One (case 14) had had a radical mastectomy 29 years before her death. No tumour was found at necropsy.

\section{OBSERVATIONS ON NINE ATYPICAL CASES}

We feel fairly confident that the 36 cases we have already discussed were suffering from the same $\sigma$ disease, with variations which are mainly quantita- $\tilde{O}$ tive, or the result of concomitant vascular disturb- N 


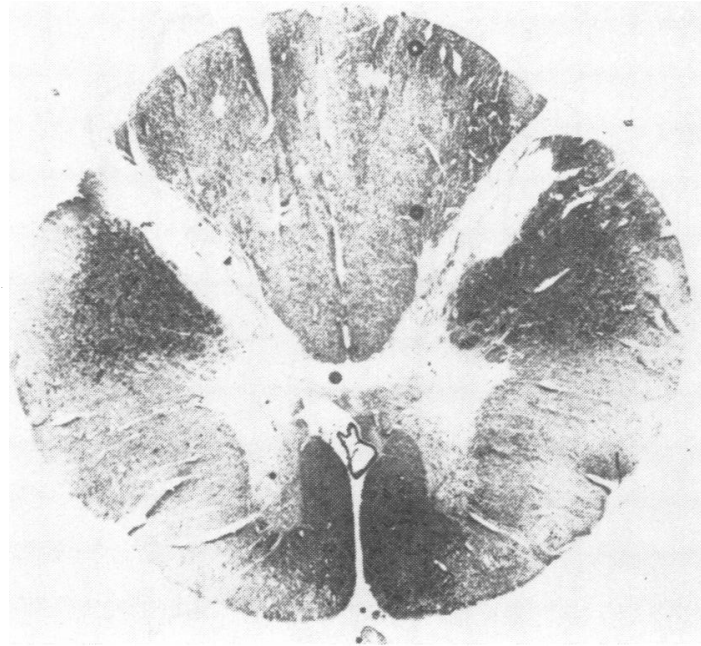

(a)

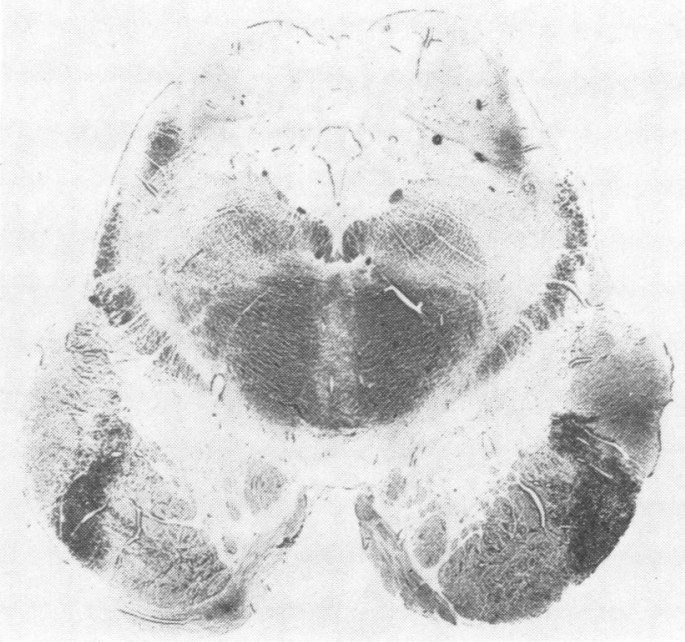

(b)

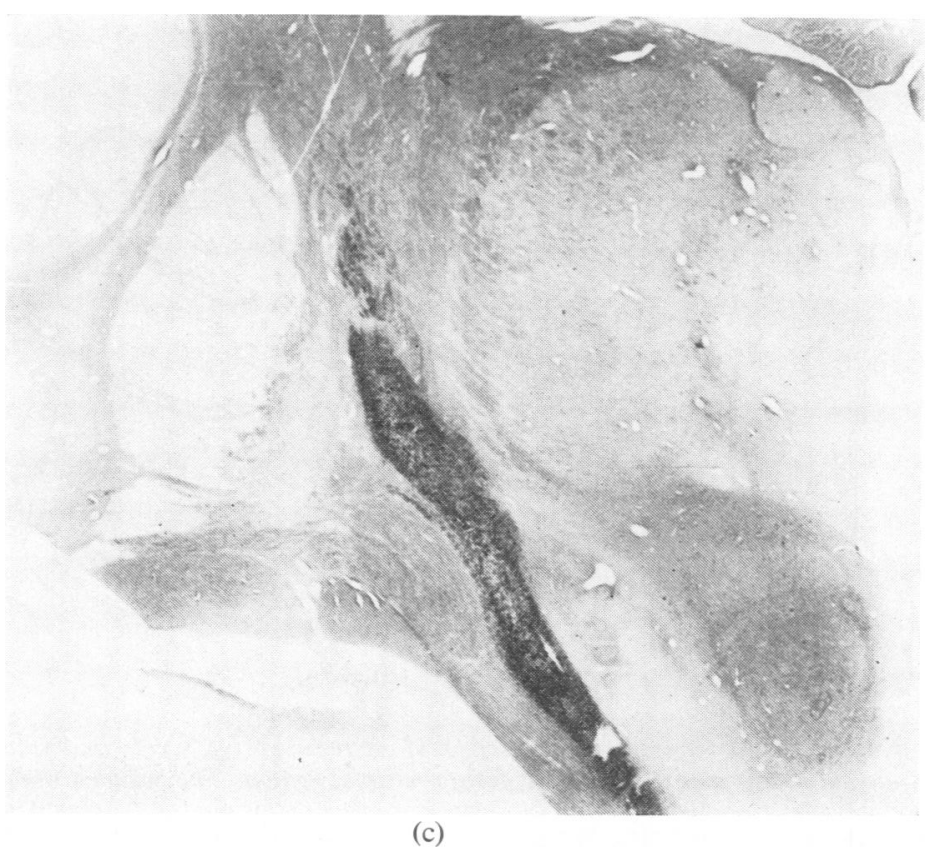

FIG. 5. Case 17. Marchi preparations for degenerating myelin showing pyramidal tract degeneration in (a) thoracic cord, (b) midbrain, and (c) internal capsule.

(c)

ances. In the remaining nine (cases 37 to 45) the question arises whether they represent extreme variants of motor neurone disease, or an extension of the same disease affecting a wider selection of nervous structures, or a fortuitous combination of motor neurone disease with some other disease, or an essentially different condition. For these cases a more detailed description is necessary.
1. TWO CASES WITH LONG DURATION, SLOW PROGRESSION, AND VERY SEVERE MOTOR CELL LOSS

CASE 37 A male university professor showed the first symptom at the age of 43 ; weakness of the anterior tibial muscle group of the left leg, followed by wasting. Two years later the left leg required a caliper, and the right leg became weak. When aged 49 , he became unable to walk and both arms became weak. One year later the 


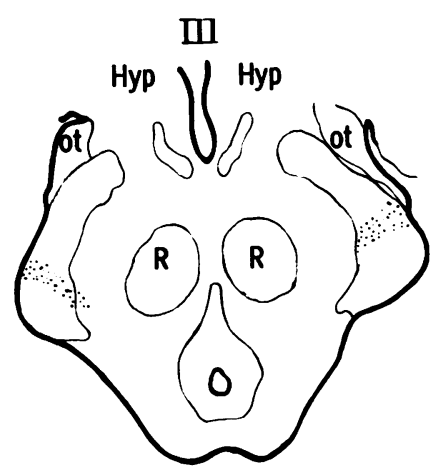

(a)

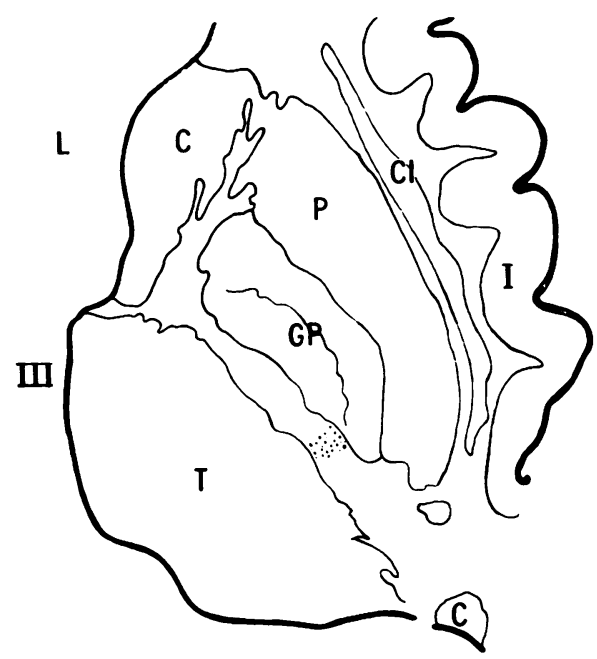

(b)

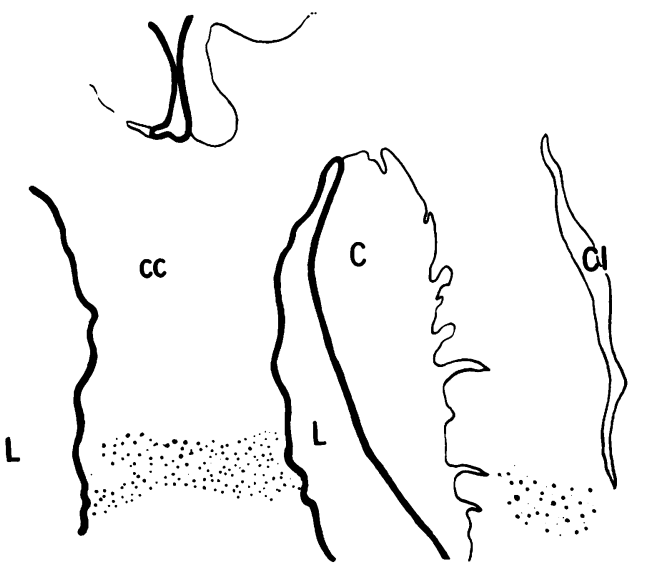

(c)

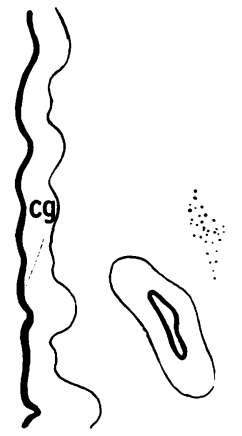

ant.

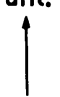

(d)

FIG. 6. Case 18. Camera lucida tracings from Marchi preparations of horizontal sections of (a) upper midbrain, (b) basal nuclei, (c) centrum ovale and corpus callosum, and (d) superior fronto-parietal region. The stippled areas indicate positive Marchi degeneration. Abbreviations: $\mathrm{C}=$ caudate nucleus; $\mathrm{cc}=$ corpus callosum; $\mathrm{cg}=$ cingulate gyrus; $\mathrm{Cl}=$ claustrum $; \mathrm{cs}=$ central sulcus; $\mathrm{GP}=$ globus pallidus; $\mathrm{Hyp}=$ hypothalamus; $\mathrm{I}=$ insula $; \mathrm{L}=$ lateral ventricle; ot $=$ optic tract $; \mathrm{P}=$ putamen; $\mathrm{R}=$ red nucleus; $\mathrm{T}=$ thalamus; $\mathrm{III}=$ third ventricle.

fingers of the left hand were paralysed. Shortly after, the right hand became too weak to write. At 52 years he was unable to feed himself or turn the pages of a book. On examination there was flaccid paralysis of four limbs. Abdominal muscles were weak, chest movements good. Intellect was unimpaired. Sensation was normal. Tendon reflexes were lost and there were no plantar responses.
Lumbar cerebrospinal fluid was normal and no abnormality was found in the blood. The Wassermann reaction was negative. When he was 54 he needed periodic assisted respiration; vital capacity was $400 \mathrm{ml}$. Terminally, after a series of cyanotic episodes with loss of consciousness, the heart ceased. The duration of illness was 11 years. Pathology The lungs showed wide areas of collapse; 


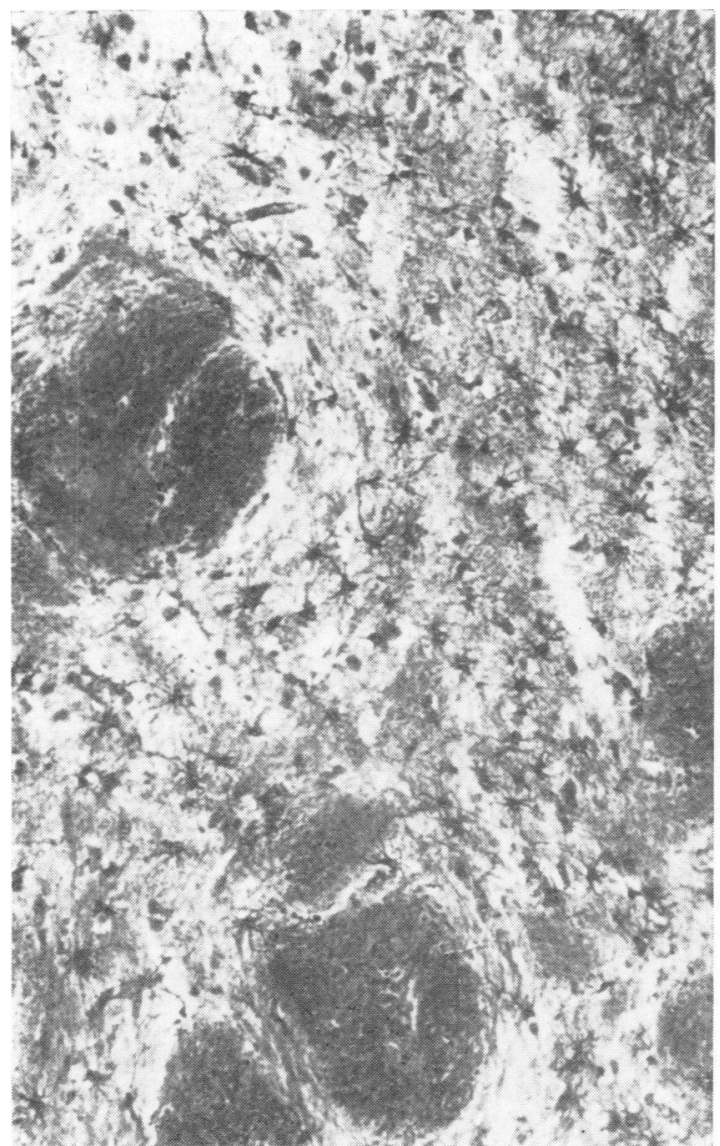

FIG. 7. Case 30. Astrocytic proliferation in grey matter of putamen. Cajal gold sublimate, $\times 130$.

purulent bronchitis and early bronchopneumonia were present. Arteries were practically free of atheroma. The muscles of legs and trunk were almost completely atrophic, with massive fatty replacement. The upper limb muscles were less severely affected, the tongue still less so.

The brain $(1,615 \mathrm{~g})$ was grossly and histologically normal for age, apart from loss of cells in the hypoglossal nuclei, moderate but widespread granular ependymitis, and terminal venous congestion. There was no detectable loss of giant pyramidal cells from the motor cortex. In the spinal cord, there was a devastating loss of nerve cells (including smaller ones) in both anterior horns. In the lower segments, this loss was almost but not quite complete. The cells of Clarke's columns, intermediolateral nuclei and posterior horns were preserved (Fig. 9). Anterior nerve roots were almost, but not quite, devoid of nerve fibres. The posterior roots were normal. The white matter of the cord showed severe vascular congestion, and there was a generalized poverty of myelin, but no obvious loss of nerve fibres, and no specific tract degeneration.

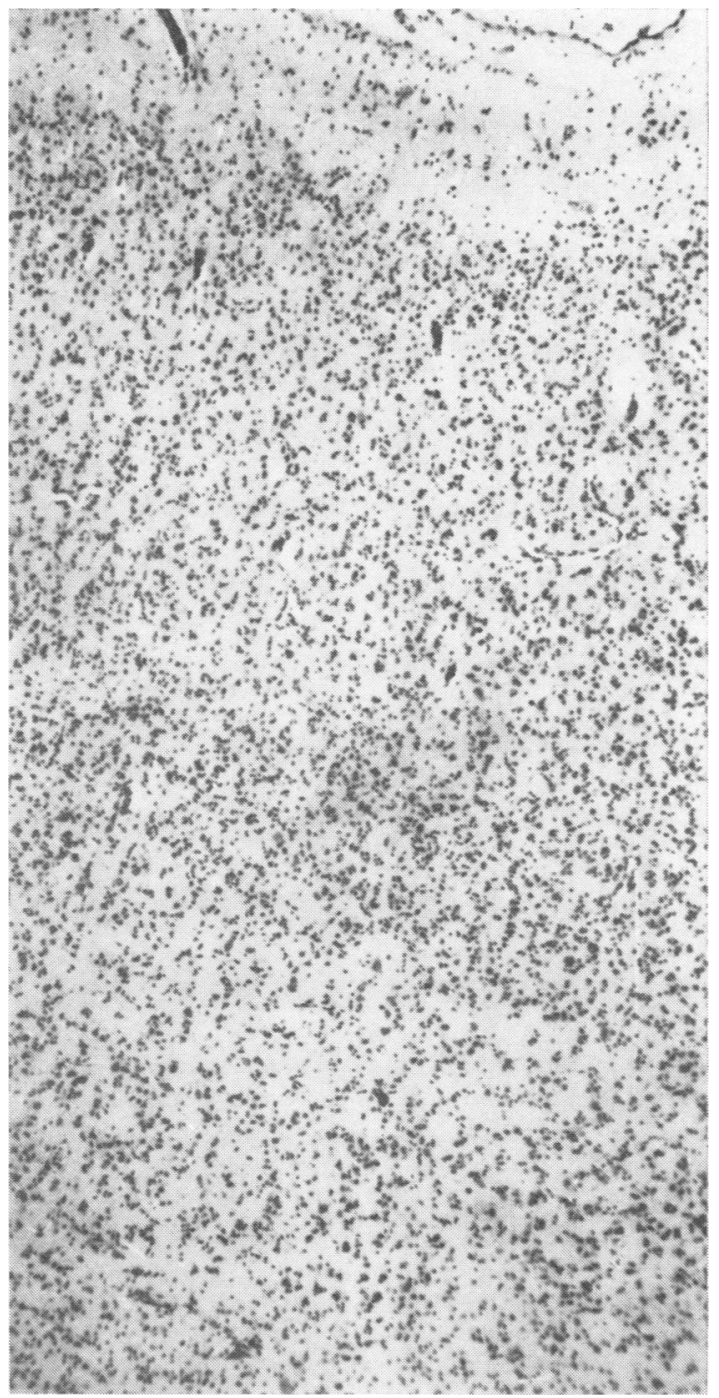

FIG. 8. Case 17. Glial proliferation in cortex. Nissl, $\times 50$.

The arteries and veins were healthy. The pia mater showed fibrous thickening.

CASE 38 A housewife had had low back pain after a fall on her back when aged 48. A year later she developed bilateral foot drop, progressing to generalized weakness of legs. On examination when aged 52 , she was hypertensive $(250 / 140 \mathrm{~mm} \mathrm{Hg})$ but otherwise healthy. There was a severe flaccid paraparesis and fasciculation in upper limb muscles and tongue. Lumbar CSF was normal. One year later she had weakness of both hands and neck and of the jaw muscles. Her voice was weak and husky. Investigation for a bruising tendency revealed that she had 


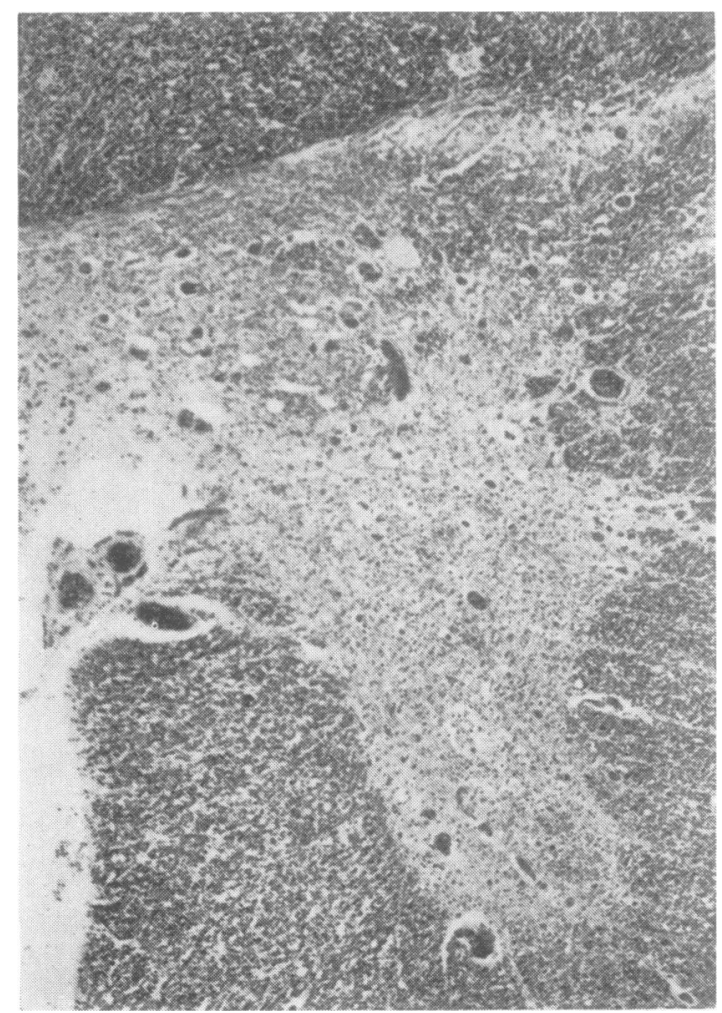

FIG. 9. Case 37. Lower thoracic cord, showing loss of anterior horn cells, with preservation of cells in lateral horn and Clarke's column. Luxol fast blue/cresyl violet, $\times 22$.

von Willebrand's disease. At the age of 55 years she was unable to walk. There was widespread wasting and fasciculation. Slow deterioration ended in death when aged 58. The duration of illness was 10 years.

Pathology Pulmonary oedema and pneumonia were present and changes of arterial hypertension with minimal atheroma. Atrophy was very severe in distal limb muscles and less severe in proximal ones, and in tongue and pharyngeal muscles.

The brain $(1,415 \mathrm{~g})$ was grossly and microscopically normal except for cell loss in the hypoglossal and other cranial motor nuclei. There was no detectable loss of giant pyramidal cells from the motor cortex. The cord showed very severe cell loss in the anterior horns at all levels, with preservation of cells in Clarke's columns and intermediolateral nuclei. No specific tract degeneration could be seen.

\section{THREE CASES WITH SEVERE PYRAMIDAL TRACT DEGENERA- TION AND MINOR DEGREE OF MOTOR CELL LOSS}

CASE 39 This patient, a woman, had had Sydenham's chorea in childhood and radical mastectomy for carcinoma, followed by radiotherapy, at the age of 50 years.
There was no recurrence, either clinically or in postmortem findings. Two years later, dysarthria and weakness of right leg began. These symptoms became steadily worse and after 15 months there was a spastic paraparesis, more severe on the right, with upgoing plantar responses and increased tendon reflexes, dysphonia, dysarthria, and dysphagia. All investigations were negative, but the blood pressure was $180 / 100 \mathrm{~mm} \mathrm{Hg}$, and a vascular lesion of the brain-stem was suspected. Death from asphyxia occurred 22 months from the onset of neurological symptoms.

Pathology Pulmonary oedema and enlargement of the heart were found. Brain and spinal cord were normal to naked eye examination. No vascular disease was present. Histologically, no denervation was seen in muscles from hand and forearm, but a few atrophic fascicles were seen in a leg muscle. Loss of motor cells in the cord was not detectable, but there was fibre loss in some anterior roots from the lower cord segments. On the other hand, there was a severe degeneration of the crossed pyramidal tracts, more marked on the right side, the white matter of the cord being otherwise normal. This could be clearly traced upwards through the pyramids and the middle thirds of the cerebral peduncles to the internal capsules and central white matter. The motor cortex appeared normal except for loss of giant pyramidal cells. There was an excess of astrocytes in the thalamus, subthalamus, and globus pallidus.

CASE 40 This woman had had migraine since childhood. At the age of 53 she complained of inability to name familiar objects. About three months later, progressive weakness of the legs began, followed by weakness of the arms and slurring of speech. On examination one yearo after the onset, she was orientated but forgetful, dysar thric, but not obviously ataxic, with a severe spastico weakness of all four limbs, and extensor plantar responses. There was no obvious muscle wasting or fasciculation and no sensory loss. Lumbar CSF was normal, with negative WR. Air encephalography showed generalized cerebral atrophy. The favoured diagnosis was Jakob-Creutzfeldt disease. She developed dysphagia and died 16 months after the onset of symptoms.

Pathology Pulmonary oedema and bronchopneumonia were present. The brain was very small $(900 \mathrm{~g}$; hind brain alone, $125 \mathrm{~g}$ ). Ventricles were moderately dilated. There was no sign of vascular disease. Histologically the striking feature was a very severe bilateral degeneration, with abundant Marchi products, of the pyramidal tracts, crossed and uncrossed, extending through the pyramids and middle thirds of the cerebral peduncles into the cerebral hemispheres (Fig. 10). The anterior and lateral columns showed diffuse myelin pallor, and scanty Marchi products. Again, motor cell loss was slight, but there was definite loss of fibres in anterior roots from the lower segments of the cord. The thalamus showed an intense proliferation of astrocytes in all parts (Fig. 11) without corresponding cell loss. The basal ganglia were not obviously affected. The cortex showed diffuse drop-out of neurones, loss of giant pyramidal cells, and astrocytosis of the subcortical U-fibre layer.

CASE 41 This man showed onset of progressive weakness 


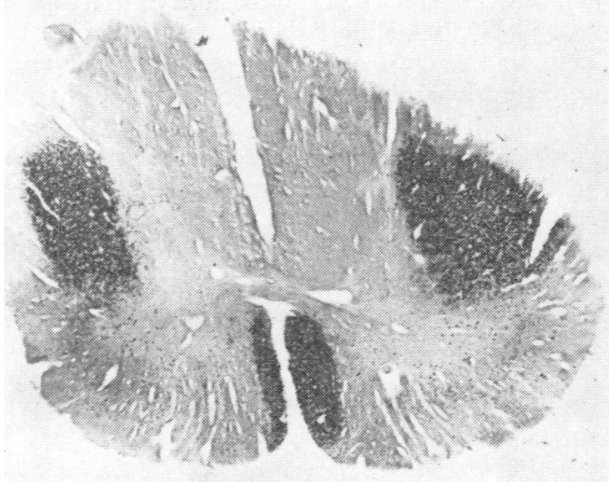

(a)

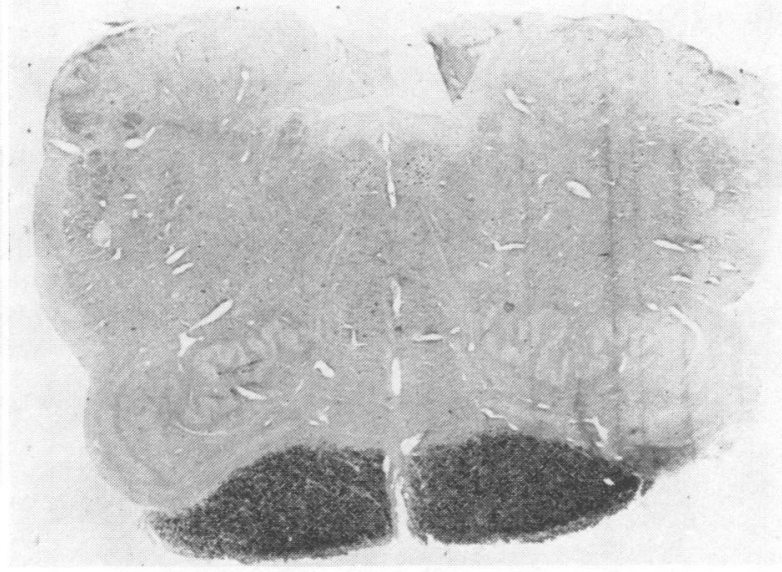

(b)

FIG. 10. Case 40. Marchi preparations for degenerating myelin showing pyramidal tract degeneration in (a) cervical cord and (b) medulla. There is lipochrome in motor cells.

in the left arm and leg at the age of 66 . On examination, five months later, there was gross weakness of the left upper limb, with increased tone in all four limbs and extensor plantar responses. There were no sensory or

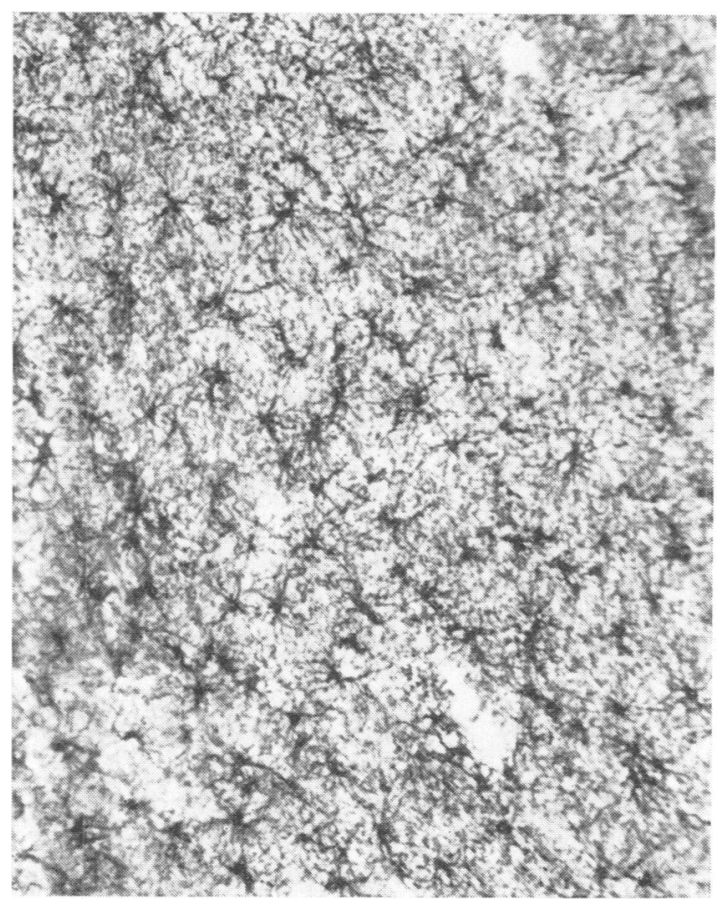

FIG. 11. Case 40. Astrocytic proliferation in thalamus. Cajal gold sublimate, $\times 130$. mental changes. Lumbar CSF was normal, with negative WR. Nerve conduction velocity was normal. There was no obvious muscle wasting or fasciculation. Steady progression took place to spastic tetraplegia, with spastic dysarthria and dysphagia, but without mental disturbance. Death from bronchopneumonia occurred 30 months from the onset of the disease.

Pathology The brain $(1,440 \mathrm{~g})$ appeared normal apart from mildly dilated ventricles. There was no sign of vascular disease. Histologically, there was severe bilateral degeneration confined to the pyramidal tracts, comparable with case 40 , but with less abundant Marchi-positive products. Loss of motor cells was likewise slight, being more marked in the cervical segments, with corresponding depletion of cervical anterior root fibres. Neuronophagia was seen in a nucleus ambiguus. There was abnormal astrocytosis, without corresponding cell loss, in the thalamus and putamen. The cerebral cortex appeared normal in most areas, but in the motor and pre-motor areas on both sides it was grossly abnormal, showing diffuse cell loss, intense astrocytic activity, and spongy change in layers 2 and 3 (Fig. 12). A few giant pyramidal cells remained in layer 5. The appearance was not that of cortical ischaemia, but of subacute polioencephalopathy.

\section{A CASE WITH EARLY ONSET AND SENSORY DISTURBANCES}

CASE 42 This man, from the late teens onward, suffered from vertigo on stooping or standing, and unexplained transient losses of consciousness. Headaches occurred frequently. Dysphonia and dysarthria began when he was aged 30. They were steadily progressive and followed by dysphagia and weakness of the right hand. On examination at the age of 33 , there was palatal paralysis, wasting, and fasciculation of the tongue and right upper limb, with loss of sensibility to pinprick and thermal stimuli on both sides of the face and upper limbs and chest. All investiga- 


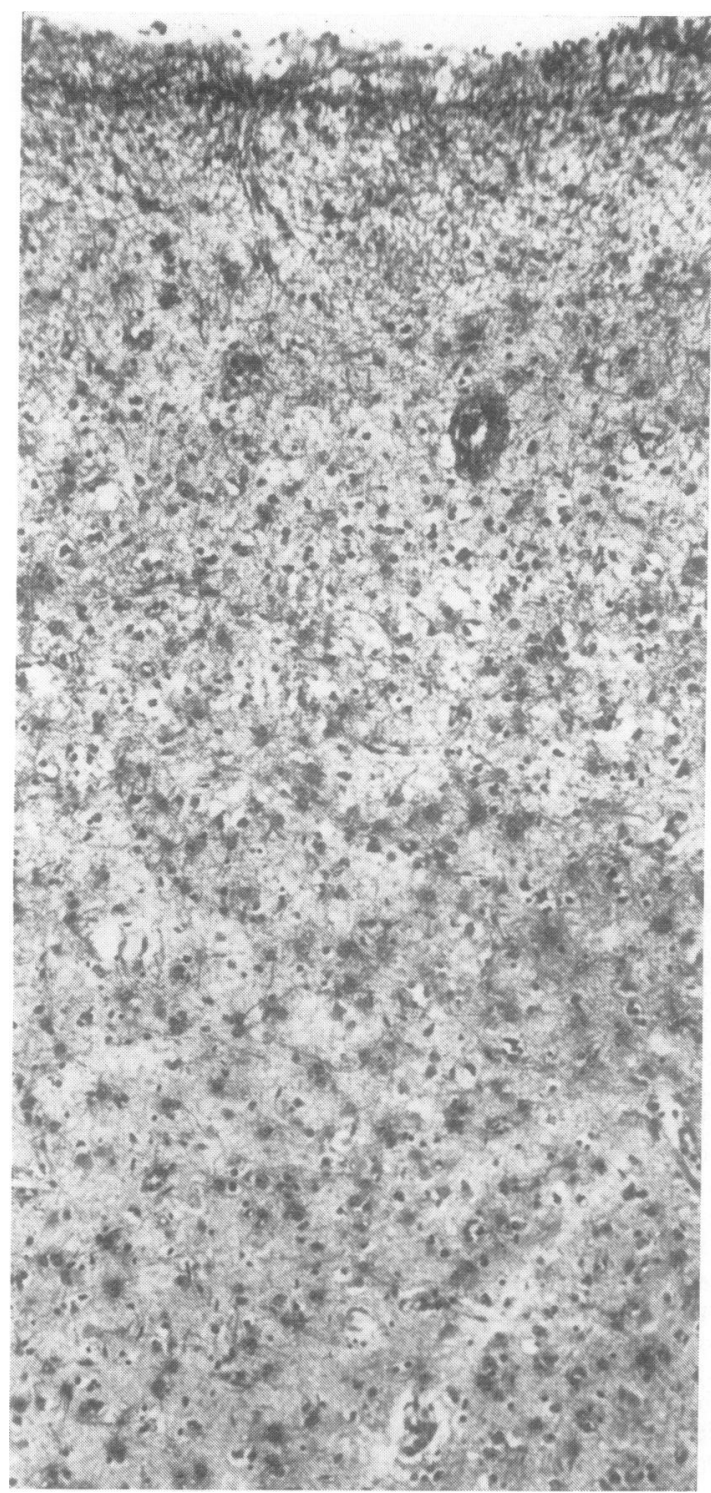

FIG. 12. Case 41. Motor cortex, showing astrocytic activity and status spongiosus. Phosphotungstic acid/haematoxylin, $\times 50$.

tions were negative. The favoured diagnosis was syringobulbia with cervical syringomyelia. A year later, all the paralytic signs had progressed: weakness, wasting, and fasciculation of muscle were observed in all parts. Surgical exploration of the posterior fossa and cervical cord was negative. He died shortly after this, four years from the onset of the speech disturbance.

Pathology The lungs showed severe bronchopneumonia; other viscera were unremarkable. There was generalized muscular wasting, most marked in hands and legs. The brain and spinal cord were normal to naked eye $\frac{\text { o }}{Z}$ examination. Histologically, there was severe loss of $\mathbb{D}$ motor cells in the cord and brain-stem, with pyknosis of many of the remaining cells. There was myelin pallor of in the anterior and lateral columns, and bilateral pyrami- $\frac{c}{0}$ dal tract degeneration, well marked in the spinal cord, visible in the pyramids, but not detected in the cerebral peduncles. The brain also showed loss of giant pyramidal cells, and abnormal gliosis in the ventral thalamus, globus pallidus, and tegmentum. In addition, there was an area of telangiectasia, with tissue loss and gliosis, in the lower. pons. There was no syrinx.

4. A CASE WITH LONG DURATION, AND ASSOCIATED WITH MALIGNANT DISEASE

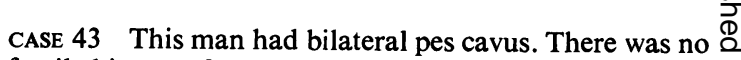
family history of nervous disorders. The first symptom, at $\stackrel{\infty}{\infty}$ the age of 61 , was weakness of the right leg followed a year later by weakness of the left leg. On examination at. the age of 63 , he had severe spastic paraparesis, with $\overrightarrow{\vec{\omega}}$ upgoing plantar responses, and some wasting of the right $\omega$ quadriceps muscle. Investigations were allnegative, except for cervical spondylosis and L5/S1 disc degeneration. On a diagnosis of spondylotic myelopathy, a cervical $\dot{\omega}$ laminectomy and decompression were performed but without effect. At the age of 67 he developed dysarthri and bulbar weakness. By the age of 69 he was unable ${ }_{\mathcal{L}}^{\omega}$ walk and his arms were spastic. He died just over eigh years from the onset of symptoms.

을 음

Pathology Aspiration pneumonia was present. Lesion of multiple myeloma were found in the spinal columb with collapse of $\mathrm{T} 10$ and $\mathrm{T} 11$ vertebral bodies, and smalle lesions in T2 and L4 vertebrae. The spinal canal was adequate, and there was no cord compression. The ki neys showed numerous hyaline casts, often calcified, characteristic of myelomatosis. Atrophy, due to denervation, was severe in leg muscles, less so in proximal upper and lower limb muscles, and relatively mild in tongue and hand muscles. The brain and spinal cord were macroscopically normal. Microscopically there were clumps of myelon a cells in the extrathecal fat, and small clusters scattered throughout the subarachnoid space, but no compressing tumour masses, and no infiltration of nervous tissue. The spinal cord showed loss of motor cells and of anterior root fibres at all levels; bilateral pyramidal tract degeneration, traceable up to the medullary pyramids, and myelin pallor of the anterior and lateral white columns. There was no sign of vascular trouble. Dorsal and intermediolateral cell columns were intact. There was probably some loss of giant pyramidal cells in the motor cortex, but no abnormal gliosis in basal nuclei.

5. TWO CASES WITH A LONG DURATION, AND MULTIPLE TRACT DEGENERATIONS

CASE 44 This woman had a negative family history. At about 46 years old there was onset of cramp-like pains and weakness in legs. On examination at the age of 50 , bilateral foot drop and weakness of both legs and of small muscles of hands were found, and fasciculation was 


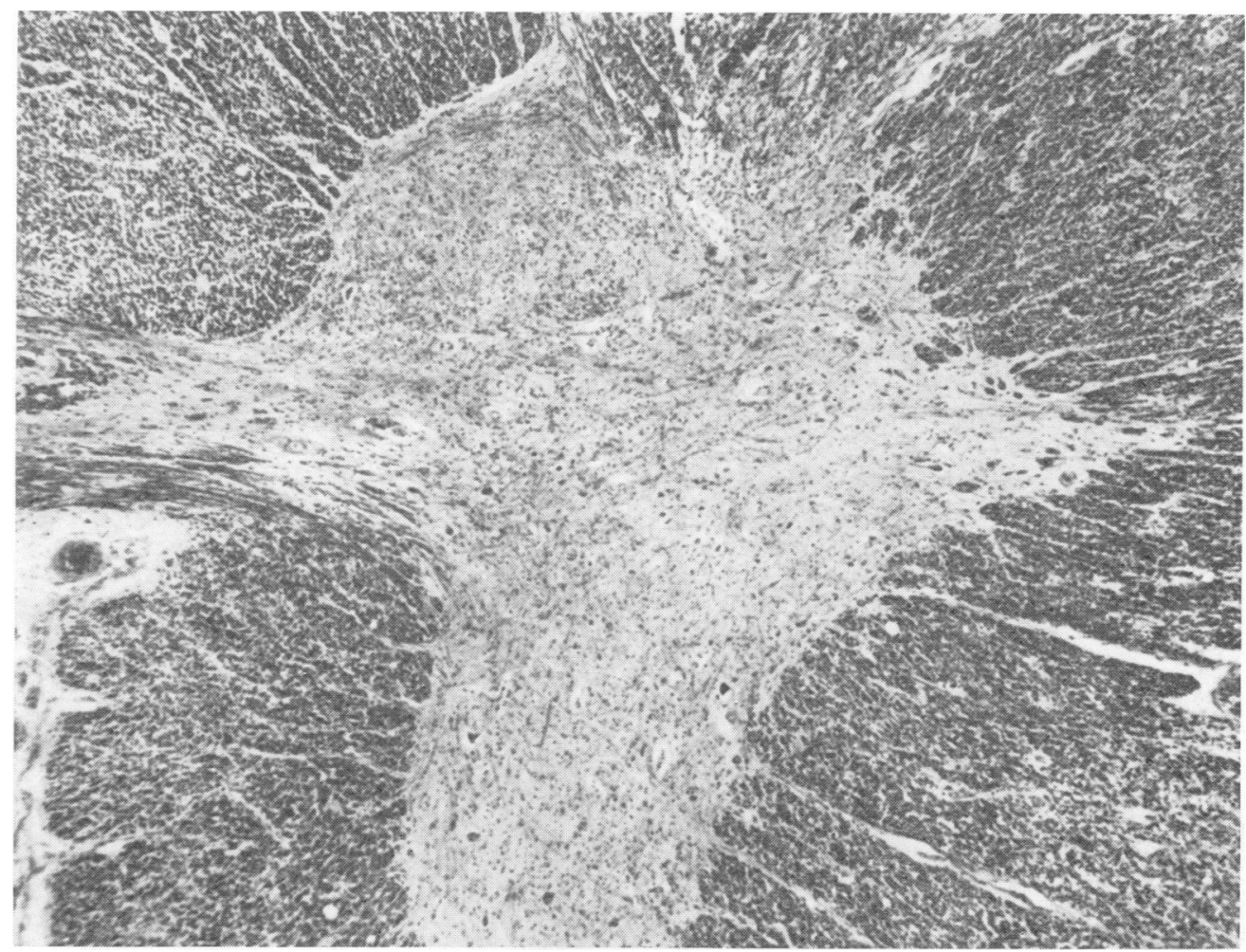

FIG. 13. Case 44. Lower thoracic cord, showing loss of cells in anterior horn and Clarke's column. Luxol fast blue/ cresyl violet, $\times 50$.

observed in upper and lower limb muscles. Plantar responses were flexor. Gait was unsteady and broadbased, but there was no definite ataxia. Sensation was normal. Electromyography suggested motor neurone disease. Other investigations were negative. Weakness progressed in all four limbs. At age 54 she was unable to stand or to turn the pages of a book. Tendon reflexes, previously brisk, became unobtainable. There were no bulbar signs and she was mentally normal. The patient died of respiratory failure seven years after the onset of weakness.

Pathology Viscera were not remarkable. The brain was normal macroscopically. The cord was slightly wasted, with atrophic anterior roots. Histologically, there was a moderate excess of astrocytes in the ventral thalamus, but the rest of the brain appeared normal. There was no detectable loss of giant cells in the motor cortex. In the brain-stem, there was myelin pallor in the pyramids, but not in the middle thirds of the cerebral peduncles. Both ventral and dorsal spinocerebellar tracts were partially degenerate. Marchi studies were negative. There was cell loss in the hypoglossal nuclei, and ghost cells in the facial nuclei. The nuclei ambigui could not be clearly seen. The cerebellum appeared normal. The lateral cuneate nuclei showed cell loss, 'ghost' cells and gliosis.
In the cord, there was very severe cell loss, with gliosis, in the anterior horns at all levels. Cell changes in the remaining motor cells included pyknosis and widespread vacuolation of cytoplasm. There was also a very severe symmetrical loss of cells in Clarke's columns (Fig. 13), but nothing to suggest ischaemia of the thoracic cord. The intermediolateral cell columns were intact. In the white columns, there was severe degeneration, with obvious loss of fibres, in both dorsal and ventral spinocerebellar tracts (Fig. 14). There was myelin pallor of the anterior and lateral columns, with more marked degeneration of the crossed pyramidal tracts. In the posterior columns, there was a peculiar pattern of myelin pallor, reminiscent of subacute combined degeneration. In fibre stains, loss of fibres was not easily detected, even in severely demyelinated areas. The appearance could not be attributed to loss of fibres in the posterior roots, which appeared normal. Anterior roots were severely depleted.

CASE 45 This man's family history, after careful inquiry, was negative for neurological disease. At the age of 49 , he noticed aching and tightness in the legs and difficulty in walking. On examination six months later he was unsteady on his legs, but not weak. Tendon jerks.were brisk in the arms, but absent in the lower limbs. Plantar 

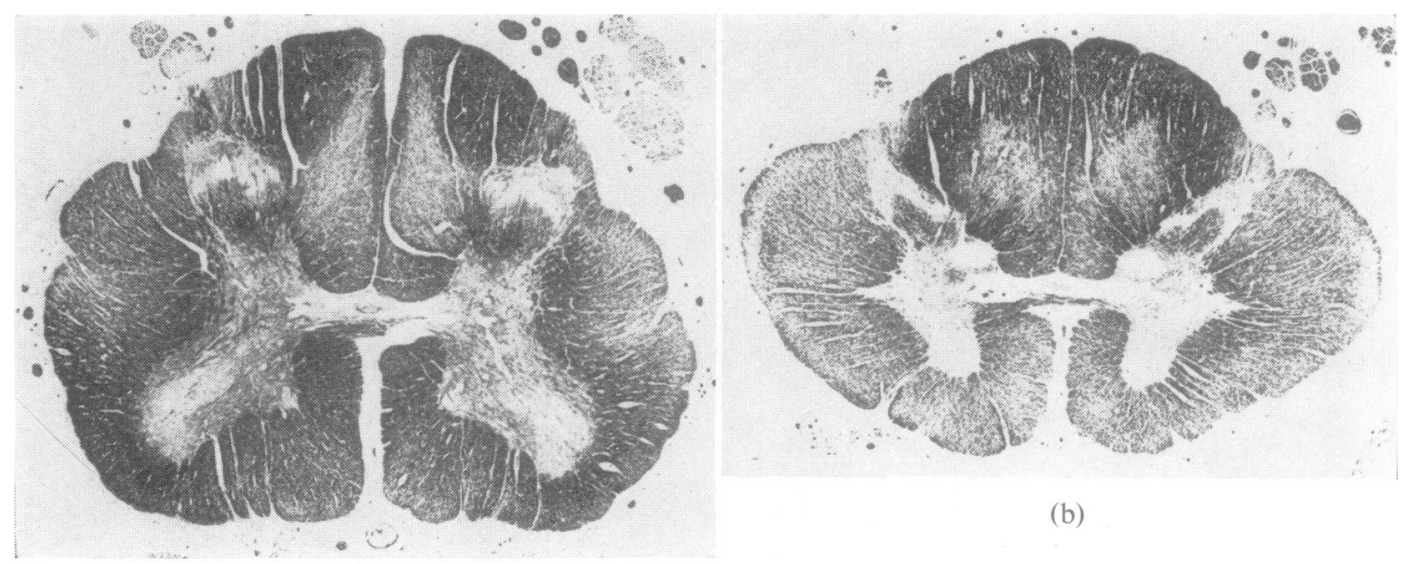

(a)

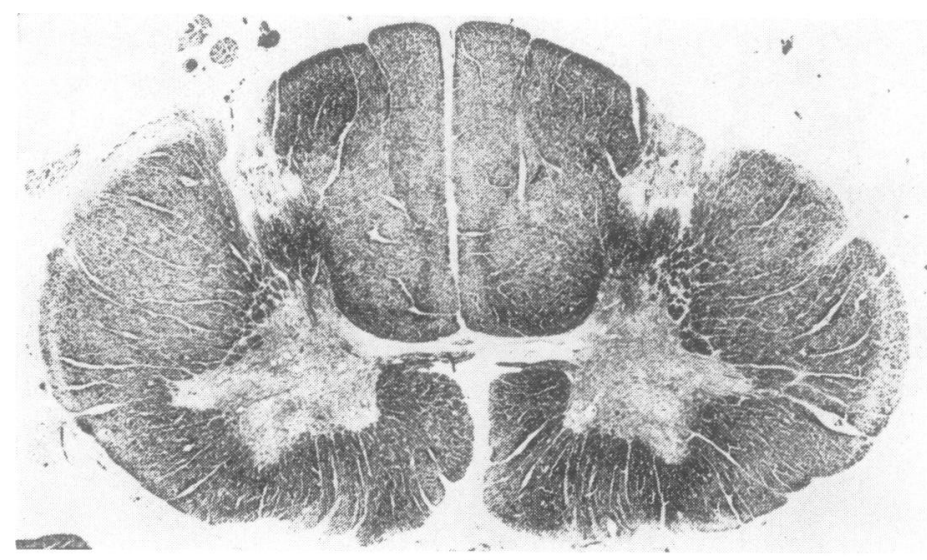

FIG. 14. Case 44. Transverse sections of spinal cord stained for myelin and showing pattern of myelin loss at (a) lumbar, (b) thoracic, and (c) cervical levels.

(c)

reflexes were extensor. There was no definite sensory loss. Lumbar CSF was normal, with negative WR. A histamine test meal showed free $\mathrm{HCl}$ in the stomach. The blood picture was normal. Dysaesthesiae in the legs continued, and walking became more difficult. At the age of 52, gross ataxia of lower limbs, and slight ataxia of the upper ones were present. Jaw jerk was brisk. Fasciculation was present in both legs and hands. Two years later, gross fasciculation was found in all limbs, and in the tongue. Speech was slurred. No sphincter disturbance or sensory loss was noted. Weakness of limbs and dysphagia were progressive. He died of asphyxia seven years after the onset of symptoms.

Pathology The lungs showed purulent bronchitis and there was severe atheroma of the abdominal aorta. Other viscera were unremarkable. The small muscles of the hands showed gross wasting, but histologically muscles from all parts, including digastrics, sternomastoids, and tongue, showed some denervation atrophy. No significant changes were found in the cerebrum. In the brainstem, there was cell loss in the hypoglossal and facial nuclei. There was also severe cell loss, with gliosis, in the lateral cuneate nuclei (Fig. 15). The dorsal and ventral spinocerebellar tracts showed severe degeneration, but the pyramids appeared intact.

The spinal cord was atrophic at all levels, particularly in the thoracic segments. All levels showed partial loss? of motor cells, the remaining cells appearing either normal, pyknotic, or ghostly. There was also severe loss of cells in Clarke's columns, whereas the intermediolateral columns appeared intact. There was a symmetrical loss of myelin in the posterior, lateral, and anterior columns, with specific tract degeneration in the dorsal and ventral $O$ spinocerebellar tracts (Fig. 16). The crossed pyramidal tracts showed degeneration, with Marchi products, up to 윽 the cervical cord, but not in the lower medulla.

\section{COMMENT}

Since the original papers of Aran (1850), Duchenne $\mathbb{N}$ (1853), and Charcot and Joffroy (1869), a mass of $\mathrm{W}$ 


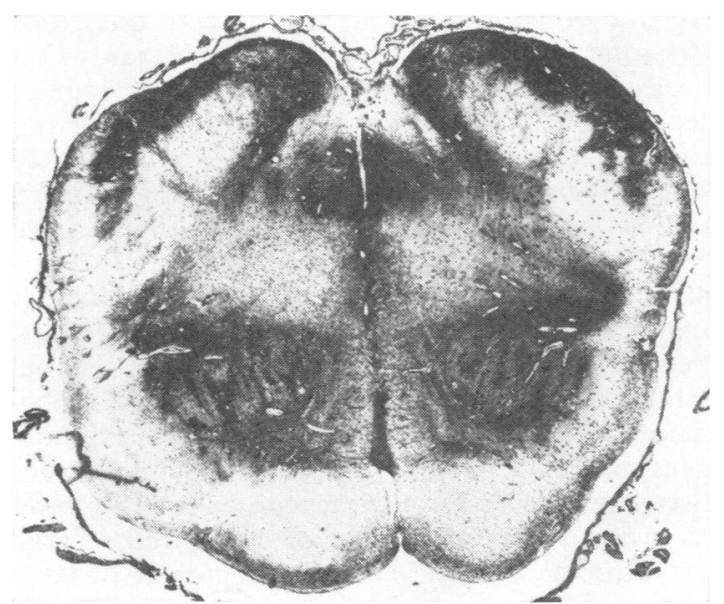

FIG. 15. Case 45. Section of lower medulla stained by Holzer's method for glial fibres and showing gliosis in inferior olives and lateral cuneate nuclei.

literature has grown up on the subject of motor neurone disease, variously called amyotrophic lateral sclerosis, progressive muscular atrophy, or progressive bulbar palsy. From this mass we have selected, for comparison with our own observations, some reports dealing with relatively large series of cases. A few of these series are of pathologically verified cases, but most are based on clinical data alone.

CLINICAL We found it was impracticable to compare the symptomatology in our series of cases with that in other series. In clinical reports it is usual to distinguish a predominantly bulbar type of case, and to divide the rest according to the predominance of upper or lower motor neurone signs, or according to

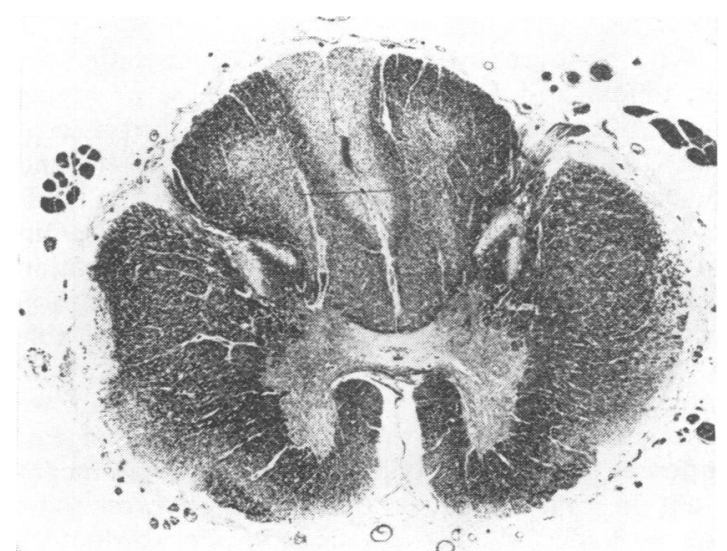

FIG. 16. Case 45. Transverse sections of cervical cord stained for myelin and showing pattern of myelin loss. whether muscular wasting in the limbs is more proximal or distal. These distinctions may be striking in the early stages of the disease; the final state, however, tends to be one of generalized muscular atrophy. In 15 of our cases the bulbar musculature was the first to be affected, but in none was this the only affected site at the time of death. Regarding the relative severity of upper and lower motor neurone damage, we found that there was, in general, a fairly good agreement between our findings and the record of the latest clinical observations; beyond this we did not pursue the matter. As a rule, we were not able to compare proximal with distal muscular atrophy.

As to sex incidence and age of onset, Table 2 shows some differences from other published series.

TABLE 2

PUBLISHED SERIES

\begin{tabular}{|c|c|c|c|c|c|}
\hline Series & Location & $\begin{array}{l}\text { Cases } \\
\text { (no.) }\end{array}$ & $\begin{array}{l}\text { Male: } \\
\text { female } \\
\text { ratio }\end{array}$ & $\begin{array}{c}\text { Age of } \\
\text { onset } d \\
\text { (range) }\end{array}$ & $\begin{array}{c}\text { Longest } \\
\text { duration } \\
(y r)\end{array}$ \\
\hline $\begin{array}{l}\text { Present series } \\
\text { Marburg (1936) }\end{array}$ & $\begin{array}{l}\text { Oxford } \\
\text { Vienna }\end{array}$ & $\begin{array}{r}45 \\
100\end{array}$ & $\begin{array}{r}1: 1 \\
1 \cdot 1: 1\end{array}$ & $\begin{array}{l}30-76 \\
20-70\end{array}$ & $\begin{array}{c}11 \\
\text { Not } \\
\text { stated }\end{array}$ \\
\hline Brain et al. (1965) & London & 86 & $2: 1$ & mean: 55 & $\begin{array}{l}\text { Not } \\
\text { stated }\end{array}$ \\
\hline $\begin{array}{l}\text { Müller (1952) } \\
\text { Swank and Putnam } \\
\text { (1943) }\end{array}$ & $\begin{array}{l}\text { Stockholm } \\
\text { New York }\end{array}$ & $\begin{array}{l}190 \\
197\end{array}$ & $\begin{array}{l}2: 1 \\
3: 1\end{array}$ & $\begin{array}{l}20-77 \\
10-80\end{array}$ & $\begin{array}{l}16 \\
15\end{array}$ \\
\hline $\begin{array}{l}\text { Wechsler, Sapirstein, } \\
\text { and Stein (1944) }\end{array}$ & New York & 81 & $2 \cdot 1: 1$ & $20-79$ & $\begin{array}{c}\text { Not } \\
\text { stated }\end{array}$ \\
\hline $\begin{array}{l}\text { Friedman and } \\
\text { Freedman }(1950)\end{array}$ & New York & 111 & $2: 1$ & $27-89$ & 10 \\
\hline $\begin{array}{l}\text { Lawyer and Netsky } \\
\text { (1953) }\end{array}$ & New York & 53 & $1 \cdot 6: 1$ & $27-70$ & 35 \\
\hline Mulder (1957) & $\begin{array}{l}\text { U.S.A. } \\
\text { (Mayo Clinic) }\end{array}$ & 100 & $2 \cdot 3: 1$ & $20-76$ & $\begin{array}{c}\text { Not } \\
\text { stated }\end{array}$ \\
\hline $\begin{array}{l}\text { Norris and Engel } \\
\text { (1965) }\end{array}$ & $\begin{array}{l}\text { U.S.A. } \\
\text { (N.I.H.) }\end{array}$ & 130 & $2 \cdot 3: 1$ & mean: 52 & $\begin{array}{l}\text { Not } \\
\text { stated }\end{array}$ \\
\hline
\end{tabular}

The sex ratio in most series is about two males to one female. In Swank and Putnam's (1943) series, the ratio is 3:1. In Marburg's (1936) it is $1: 1$, as in the present series. There is no easy explanation of this discrepancy. In our own series the age of onset in one case was 30; apart from this, the earliest onset was at the age of 46 . In other series, onset in the fourth decade appears to be fairly common, and in the third decade not at all rare. In the series of Swank and Putnam (1943), there are cases with onset in the 'teens. Such cases, we feel, should be regarded with some reserve in the absence of histological verification. Figure 17 shows histograms of two series-our own and that of Lawyer and Netsky (1953). The shapes of the histograms are similar, but ours has a mean nearly 10 years later than theirs. This is unlikely to be an effect of differences in the selection of cases, and suggests that environmental factors- 


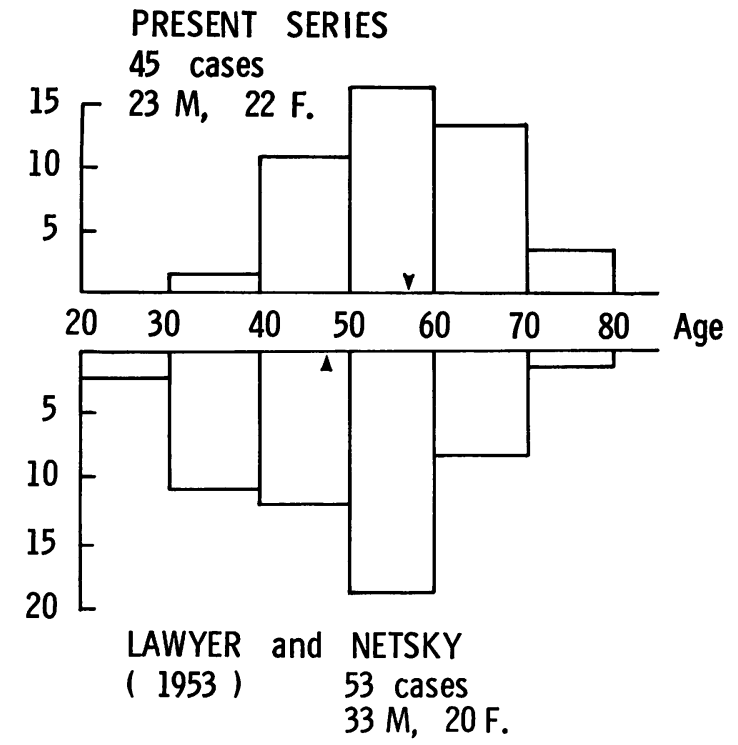

FIG. 17. Double histogram showing age of onset in two series of cases verified at necropsy. Arrowheads indicate mean age of onset.

social, genetic, or climatic-may be operative in determining the age at which the disease shows itself.

It has recently been suggested (Norris and Engel, 1965; Brain, Croft, and Wilkinson, 1965) that a clinical state similar to motor neurone disease (with, it is supposed, a similar pathology) occurs as a complication of malignant disease. We find the evidence presented for this view unconvincing, and our own series provides no evidence for or against it. Our case 28 was found at death to have a carcinoma of the kidney; case 14 had had a mastectomy for carcinoma 26 years before the onset of motor neurone disease, without recurrence; and case 37 had had a mastectomy two years before the onset of symptoms, again without recurrence. Case 41 was found at necropsy to have myelomatosis. In the age group with which we are dealing, this is not an unduly high proportion of sufferers from malignant disease; and until there is more pathological evidence on the subject, we are content to regard these as instances of motor neurone disease associated by coincidence with malignancy.

PATHOLOGical In the first place, we wish to draw attention to some of the histological features of the 36 cases which we regard as typical cases of motor neurone disease; in particular, the features in which our findings differ from current accounts of the disease. First, there are eight cases in which the pyramidal tracts appear normal in myelin and Marchi preparations. The mean survival time in this group was somewhat shorter than that for the rest of the 'typical' cases, and it is possible that pyramidal degeneration would have occurred if they had survived longer, but this is by no means certain. In 'atypical' cases with durations of 10 years or more, such as cases 37 and 38 , we may safely suppose that the pyramidal tracts were never at risk. Many authors state, or imply, that the pyramidal tracts are always involved to some extent in this disease; Lawyer and Netsky (1953), however, found two cases without pyramidal involvement in their series of 53 pathologically verified cases. The existence of such cases gives support to the use of the term 'motor neurone disease', which applies to degeneration of either lower or upper motor neurones, or both, rather than 'amyotrophic lateral sclerosis', a term that stresses a pathological feature which may be absent, or at least undetectable by conventional methods. It is worth mentioning that in the group without pyramidal lesions the clinical diagnosis in nearly every case was of motor neurone disease, even in the absence of signs of upper motor neurone involvement.

The second point which we wish to stress is the frequency of asymmetrical lesions in the cord (cfo Figs. 3 and 4). This corresponds with the well-known $c$ clinical observation that symptoms are often asymid metrical, at any rate in the early stages of the disease $\stackrel{0}{\circ}$ This asymmetry has to be borne in mind when cons $c$ sidering questions of aetiology and pathogenesis $ᄋ$

Thirdly, we would point to the absence of specifie spinocerebellar tract degeneration in all but two cases (44 and 45), both of which were atypical in other respects. Admittedly, in the presence of a generalized pallor of the subpial myelin, such as was frequently seen, specific tract degeneration may be difficult to detect. In such cases, we based our conclusion on the finding of normal-looking Clarke's columns.

On the question whether the degeneration of pyramidal and other tracts is a process of "dying back' of axons towards the cell body, our observations conform with those of Davison (1941) and others, who found that pyramidal degeneration tends to be more severe at lower than at higher levels. Out of 35 cases in which pyramidal tract degeneration was present, there were 14 in which the degeneration could not be traced above a certain level (see Table 1). Regarding the myelin pallor of the anterior and lateral columns observed in 26 cases, when we attempted to compare the severity of this change at different levels of the cord our findings were inconstant. In some cases the thoracic cord appeared to be the most affected, in others the cervical or the lumbar cord. Thus we could not confirm or refute Greenfield's (1958) suggestion that descending fibres are 
preferentially affected; furthermore, we were unable to decide, in any of the cases, whether the loss of myelin was accompanied by a corresponding loss of axis cylinders. In cases 44 and 45 (both 'atypical') a severe loss of myelin in the posterior columns was clearly not accompanied by a corresponding fibre loss.

Lastly, before discussing the nosological 'placing' of our nine 'atypical' cases, we would stress the great variability of lesions in the 'typical' series. There is one feature common to all-that is, loss of lower motor neurones. Apart from this there are various degenerative changes, present in some cases and absent in others. These include pyramidal tract degeneration, loss of myelin in the anterior and lateral white columns, loss of cells in the motor cortex, cortical gliosis and status spongiosus, gliosis in the thalamus and/or basal ganglia, and local or diffuse loss of fibres in the cerebral white matter, including the corpus callosum ${ }^{1}$. In other words, motor neurone disease is not merely a simultaneous degeneration of upper and lower motor neurones. It may involve either more or less than these two systems, and the relative severity of the lesions in different structures varies from case to case.

Nine cases (37 to 45) fell outside our somewhat arbitrary limits for 'typical' motor neurone disease. Two of these (cases 42 and 43) we are content to regard as cases of motor neurone disease complicated, but not caused, by a second condition-in the one case, a vascular malformation in the brain-stem; in the other, myelomatosis. The early onset in case 42 , and the long duration in case 43 , are not in themselves sufficient reasons to separate these two cases from the main group.

Cases 37 and 38 differ from the 'typical' cases in group 1 , firstly in their slowly progressive history of ascending paralysis, and secondly by the absence of detectable changes in the brain. In some ways they resemble the cases described by Pearce and Harriman (1966) under the heading "chronic -spinal muscular atrophy', but differ in that the onset of the disease in their cases was considerably earlier, and the progression even slower. Further, two of their cases showed upper motor neurone signs. These authors do not claim that the disease which they describe can be clearly separated from the more familiar forms of progressive muscular atrophy: rather, that they form part of a range of conditions which merge into one another. In the present state of knowledge, this seems to be the most reasonable approach.

\footnotetext{
${ }^{1}$ In this connection, we should like to draw attention to the work of Probst (1898, 1903), whose observations on the cerebral pathology in motor neurone disease have been surprisingly neglected by subsequent writers.
}

In contrast to cases 37 and 38, cases 39,40 , and 41 represent the opposite extreme-minimal motor cell loss, with severe pyramidal tract degeneration and well-marked changes in the brain. For these, some authors would prefer the diagnosis of 'primary lateral sclerosis'. In cases 44 and 45 , the disease was of long duration, and the spinal cords showed, in addition to the typical lesions of motor neurone disease, degeneration of the spinocerebellar pathways and posterior columns, resulting in a pattern reminiscent of subacute combined degeneration. It is worth noting that sensory loss, if it was present at all, was not severe enough in either case to have been noted clinically, and the clinical diagnosis in both was of motor neurone disease. The picture in these cases, though not a well-recognized one, is by no means unique. It corresponds closely to the description given by Engel, Kurland, and Klatzo (1959) of three familial cases of a disease clinically indistinguishable from motor neurone disease, but with marked involvement of ascending tracts. The same authors quote similar cases, both familial and sporadic, from the earlier literature. They discuss the relationship of these cases to 'classical' motor neurone disease and other degenerative conditions.

Our examination of the central nervous system in these $\mathbf{4 5}$ cases was, of necessity, not exhaustive, but as far as we can tell there are at least two (37 and 38) in which the lesion was confined to a single systemthe lower motor neurone-and two (44 and 45) in which systems were involved which were unaffected in the remainder. The situation is closely analogous to that obtaining in another type of system degeneration, namely olivo-ponto-cerebellar atrophy. Here, too, individual cases show lesions of very variable severity in a selection of structures (Welte, 1939; Graham and Oppenheimer, 1969). The structures 'at risk' in the latter condition overlap little, if at all, with those at risk in motor neurone disease; but the time course of these two diseases, their peak age of onset, and their histological features, are very similar.

If we take the view that motor neurone disease is merely part of the spectrum of a particular type of multiple system atrophy, there is no reason to draw a line between it and the condition usually referred to as the amyotrophic form of Jakob-Creutzfeldt disease (Alemà and Bignami, 1959; Khochneviss, 1960; Kirschbaum, 1968). Since the completion of our series we have examined a case of this kind, with severe spongy degeneration of the cerebral cortex and intense gliosis of the striatum. The lesions in the spinal cord, on the other hand, are typical of motor neurone disease, with severe motor cell loss and pyramidal degeneration ascending as far as the lower brain-stem. Cases 40 and 41, we would suggest, represent an intermediate stage in which the cerebral 
lesions are milder than in a full-blown encephalopathy of the Jakob-Creutzfeldt type.

The idea that classical motor neurone disease may be part of a spectrum which includes the subacute encephalopathies of middle age, which are generally referred to as Jakob-Creutzfeldt disease, is not new (Meyer, 1929); and in the near future it may be possible to put it to the test. During the last few years, a number of non-inflammatory, slowly progressive, degenerative diseases have been identified, in which there appears to be a transmissible 'agent', capable of producing a similar slow degeneration in the central nervous tissues of experimental animals. The existence of such an agent has been demonstrated in scrapie, a subacute presenile polioencephalopathy occurring in sheep (Pattison, Gordon, and Millson, 1959; Beck, Daniel, and Parry, 1954), in human kuru (Beck, Daniel, Alpers, Gajdusek, and Gibbs, 1966; Alpers, 1969), and, most recently, in a human case of subacute presenile polio-encephalopathy (Gibbs, Gajdusek, Asher, Alpens, Beck, Daniel, and Matthews, 1968). A report of similar 'transmission' of motor neurone disease (Zil'ber, Bajdakova, Gardaš'jan, Konovalov, Bunina: and Barabadze, 1963) has been received with some critical reserve (Kurland, 1965; Johnson, 1968), but will undoubtedly be followed up by further experiments. So far, very little has been discovered about the role of such 'agents' in naturally-occurring diseases.

On the basis of these transmission experiments, it has been claimed (Gibbs and Gajdusek, 1968) that kuru and scrapie provide us with an experimental model for the study of 'degenerative' diseases of the central nervous system, and of motor neurone disease in particular. We agree with this view, but we do not agree that, as Gibbs and Gajdusek maintain, the transmission experiments prove that the diseases in question are acquired, in normal circumstances, by infection. In the case of scrapie there are strong arguments against the view that the natural disease is merely the result of infection by a 'slow' virus (see Haig, 1969; Parry, 1969). An alternative theory, in which hereditary factors play a leading role, has been put forward by Darlington (1969). From present evidence, it seems that a new class of disease (not merely a number of new diseases which can be fitted into an old classification) is in the process of being discovered. From the clinical and the histological point of view, kuru and scrapie, like motor neurone disease, belong to the group of primarythat is, hitherto unexplained-neuronal degenerations. Elucidation of the pathogenesis of scrapie seems to us the most promising approach to the elucidation both of motor neurone disease and of other 'abiotrophies', the origin of which has been until now a total mystery.

\section{CONCLUSIONS}

What we have described above is a group of middleaged or elderly patients afflicted with a progressive loss of lower motor neurones, from no known cause. Most of them also show degenerative changes in 7 other parts of the central nervous system, in particular the pyramidal system. 'Motor neurone disease' is a convenient diagnostic label for all these casesmore accurate, and less cumbersome, than 'amyotrophic lateral sclerosis'. For the most part these cases conform, clinically and pathologically, with textbook accounts of this condition, but a few do not. We are strongly opposed to the invention of new diagnostic labels for such non-conforming cases. The labelling of diseases of unknown aetiology is a matter of practical convenience, and the invention of new labels would only be justified if and when particular causal agents were identified. For the time being, we consider that it is practical and convenient to retain the label of 'motor neurone disease', while recognizing that some cases show peculiar clinical and pathological features; and that these cases can be cited as evidence that 'classical' motor neurone disease is not a well-defined entity, but rather a prominent band $i \overline{\mathbf{Q}} \hat{\omega}$ a wide spectrum of subacute or chronic multipli $\mathscr{W}_{\infty}$ system atrophies, with a predilection for certain parti of the motor system, and a tendency to occur in middle age.

The authors acknowledge with thanks their indebteds ness to the consultants of the Oxford Region for the use of their clinical records and to the Spastics Society for a grant towards technical assistance. The majority of the histological sections used were prepared by $\mathrm{Mr}$. Ron Beesley.

\section{REFERENCES}

Alemà, G., and Bignami, A. (1959). Polioencefalopatia degenerativa subacuta del presenio con stupore acinetico e rigidità decorticata con mioclonie. Riv. sper. Freniat., 83, 1485-1623.

Alpers, M. (1969). Kuru: clinical and aetiological aspects. In Virus Diseases and the Nervous System, pp. 83-97, edited by C. W. M. Whitty, J. T. Hughes, and F. O. MacCallum. Blackwell Scientific Publications: Oxford.

Aran, F. A. (1850). Recherches sur une maladie non encore décrite du système musculaire (atrophie musculaire progressive). Arch. gén. Méd., 24, 5-35, and 172-214.

Beck, E., Daniel, P. M., Alpers, M., Gajdusek, D. C., and Gibbs, C. J. (1966). Experimental 'Kuru' in chimpanzees. A pathological report. Lancet, 2, 1056-1059.

Beck, E., Daniel, P. M., and Parry, H. B. (1964). Degeneration of the cerebellar and hypothalamoneurohypophysial systems in sheep with scrapie; and its relationship to $\sigma$ human system degenerations. Brain, 87, 153-176.

Bertrand, I., and Van Bogaert, L. (1925). La sclérose latérale amyotrophique. (Anatomie pathologique.) Rev. neurol., 1, 779-806. 
Brain, Lord, Croft, P. B., and Wilkinson, M. (1965). Motor neurone disease as a manifestation of neoplasm (with a note on the course of classical motor neurone disease). Brain, 88, 479-500.

Charcot, J. M., and Joffroy, A. (1869). Deux cas d'atrophie musculaire progressive avec lésions de la substance grise et đes faisceaux antérolatéraux de la moelle épinière. Arch. physiol. (Paris), 2, 354-367, 629-649, 744-760.

Darlington, C. D. (1969). Virus and provirus in the evolution of disease. In Virus Diseases and the Nervous System, pp. 133-138, edited by C. W. M. Whitty, J. T. Hughes, and F. O. MacCallum. Blackwell Scientific Publications: Oxford.

Davi ion, C. (1941). Amyotrophic lateral sclerosis. Origin and extent of the upper motor neurone lesion. Arch. Neurol. Psychiat. (Chic.), 46, 1039-1056.

Duchenne, G. B. (1853). Étude comparée des lésions anatomiques dans l'atrophie musculaire progressive et dans la paralysie générale. Un. méd. Prat. franç., 7, 202, 215, $219,243,246,250$, and 254.

Engel, W. K., Kurland, L. T., and Klatzo, I. (1959). An inherited disease similar to amyotrophic lateral sclerosis with a pattern of posterior column involvement. An intermediate form? Brain, 82, 203-220.

Friedman, A. P., and Freedman, D. (1950). Amyotrophic lateral sclerosis. J. nerv. ment. Dis., 111, 1-11.

Gibbs, C. J., and Gajdusek, D. C. (1968). Kuru: a prototype subacute infectious disease of the nervous system as a model for the study of amyotrophic lateral sclerosis, In Motor Neuron Diseases, pp. 269-279, edited by F. H. Norris, and L. T. Kurland. Grune and Stratton: New York.

Gibbs, C. J., Gajdusek, D. C., Asher, D. M., Alpers, M. P., Beck, E., Daniel, P. M., and Matthews, W. B. (1968). Creutzfeldt-Jakob disease (Spongiform encephalopathy): transmission to the chimpanzee. Science, 161, 388-389.

Glees, P. (1943). The Marchi reaction: its use on frozen sections and its time limit. Brain, 66, 229-232.

Graham, J. G., and Oppenheimer, D. R. (1969). Orthostatic hypotension and nicotine sensitivity in a case of multiple system atrophy. J. Neurol. Neurosurg. Psychiat., 32, 28-34.

Greenfield, J. G. (1958). Chapter 9 in Neuropathology, by Greenfield, J. G., Blackwood, W., McMenemey, W. H., Meyer, A., and Norman, R.M. Edward Arnold: London.

Haig, D. A. (1969). The virology of scrapie. In Virus Diseases and the Nervous System, pp. 129-131, edited by C. W. M. Whitty, J. T. Hughes, and F. O. MacCallum. Blackwell Scientific Publications: Oxford.

Hughes, J. T., and Brownell, B. (1966). Spinal cord ischaemia due to arteriosclerosis. Arch. Neurol.(Chic.), 15, 189-202.

Johnson, R. T. (1968). Virologic studies and summary of Soviet experiments on the transmission of amyotrophic lateral sclerosis (ALS) to monkeys. In Motor Neuron Diseases, pp. 280-282, edited by F. H. Norris and L. T. Kurland. Grune and Stratton: New York.

Khochneviss, A. A. (1960). Contribution a l'étude du Syndrome de Creutzfeldt-Jakob. M.D. Thesis. Editions A.G.E.M.P.: Paris.

Kirschbaum, W. R. (1968). Jakob-Creutzfeldt disease. American Elsevier Publishing Co.: New York.
Kurland, L. T. (1965). Amyotrophic lateral sclerosis: a reappraisal. In Slow, Latent and Temperate Virus Infections, pp. 13-22, edited by D. C. Gajdusek, C. J. Gibbs, and M. Alpers. National Institute of Neurological Diseases and Blindness: Washington.

Lawyer, T., and Netsky, M. G. (1953). Amyotrophic lateral sclerosis. A clinicoanatomic study of fifty-three cases. Arch. Neurol. Psychiat. (Chic.), 69, 171-192.

Marburg, O. (1936). Die chronisch progressiven nuclearen Amyotrophien. Die amyotrophische Lateralsklerose. In Handbuch der Neurologie, pp. 524-605, vol. 16, edited by $O$. Bumke and $O$. Foerster. Springer: Berlin.

Meyer, A. (1929). Uber eine der amyotrophischen Lateralsklerose nahestehende Erkrankung mit psychischen Störungen. Z. ges Neurol. Psychiat., 121, 107-138.

Mulder, D. W. (1957). The clinical syndrome of amyotrophic lateral sclerosis. Proc. Mavo Clin., 32, 427-436.

Müller, R. (1952). Progressive motor neurone disease in adults. A clinical study with special reference to the course of the disease. Acta psychiat. (Kbh.), 27, 137-156.

Norris, F. H., and Engel, W. K. (1965). Carcinomatous amyotrophic lateral sclerosis. In The Remote Effects of Cancer on the Nervous System, pp. 24-34, edited by W. R. Brain, and F. H. Norris. Grune and Stratton: New York.

Parry, H. B. (1969). Scrapie-natural and experimental. In Virus Diseases and the Nervous System, pp. 99-105, edited by C. W. M. Whitty, J. T. Hughes, and F. O. MacCallum. Blackwell Scientific Publications: Oxford.

Pattison, I. H., Gordon, W. S., and Millson, G. C. (1959). Experimental production of scrapie in goats. J. comp. Path., 69, 300-312.

Pearce, J., and Harriman, D. G. F. (1966). Chronic spinal muscular atrophy. J. Neurol. Neurosurg. Psychiat., 29, 509-520.

Probst, M. (1898). Zu den fortschreitenden Erkrankungen der motorischen Leitungsbahnen. Arch. Psychiat. Nervenkr., 30, 766-844.

Probst, M. (1903). Zur Kenntnis der amyotrophischen Lateralsklerose. S-B. Akad. Wiss. Wien., 112, Abt. 3, 683-824.

Smith, M. C. (1956). Observations on the extended use of the Marchi method. J. Neurol. Neurosurg. Psychiat., 19, 67-73.

Smith, M. C. (1960). Nerve fibre degeneration in the brain in amyotrophic lateral sclerosis. J. Neurol. Neurosurg. Psychiat., 23, 269-282.

Swank, R. L., and Putnam, T. J. (1943). Amyotrophic lateral sclerosis and related conditions. A clinical analysis. Arch. Neurol. Psychiat. (Chic.), 49, 151-177.

Wechsler, I. S., Sapirstein, M. R., and Stein, A. (1944). Primary and symptomatic amyotrophic lateral sclerosis. A clinical study of 81 cases. Amer. J. med. Sci., 208, 70-81.

Welte, E. (1939). Die Atrophie des Systems des Brückenfusses und der unteren Oliven. Arch. Psychiat. Nervenkr., 109, 649-698.

Zil'ber, L. A., Bajdakova, Z. L., Gardašjan, A. N., Konovalov, N. V., Bunina, T. L., and Barabadze, E. M. (1963). Study of the etiology of amyotrophic lateral sclerosis. Bull. Wld Hlth Org., 29, 449-456. 